\title{
Modulation of Calcium Oxalate Crystal Growth and Protection from Oxidatively Damaged Renal Epithelial Cells of Corn Silk Polysaccharides with Different Molecular Weights
}

\author{
Jia-Yun Chen $\mathbb{D}$, ${ }^{1,2}$ Xin-Yuan Sun $\mathbb{D}^{3}$, and Jian-Ming Ouyang $\mathbb{D}^{1,2}$ \\ ${ }^{1}$ Department of Chemistry, Jinan University, Guangzhou 510632, China \\ ${ }^{2}$ Institute of Biomineralization and Lithiasis Research, Jinan University, Guangzhou 510632, China \\ ${ }^{3}$ Department of Urology, Minimally Invasive Surgery Center, The First Affiliated Hospital of Guangzhou Medical University, \\ Guangdong Key Laboratory of Urology, Guangzhou Institute of Urology, China
}

Correspondence should be addressed to Jian-Ming Ouyang; toyjm@jnu.edu.cn

Received 5 November 2019; Accepted 6 January 2020; Published 22 January 2020

Academic Editor: Paolo Tucci

Copyright (C) 2020 Jia-Yun Chen et al. This is an open access article distributed under the Creative Commons Attribution License, which permits unrestricted use, distribution, and reproduction in any medium, provided the original work is properly cited.

Corn silk polysaccharide $(\mathrm{CSP} 0$; molecularweight $=124 \mathrm{kDa})$ was degraded by ultrasonication to obtain five degraded polysaccharides, namely, CSP1, CSP2, CSP3, CSP4, and CSP5, with molecular weights of 26.1, 12.2, 6.0, 3.5, and 2.0 kDa, respectively. The structures of these polysaccharides were characterized by FT-IR, ${ }^{1} \mathrm{H}$ NMR, and ${ }^{13} \mathrm{C}$ NMR analyses. The antioxidant activities, including scavenging ability for hydroxyl radicals and DPPH free radicals, chelation ability for $\mathrm{Fe}^{2+}$ ions, and reducing ability of CSP increased with decreased molecular weight of CSPs within 6.0 to $124 \mathrm{kDa}$. However, antioxidant activity weakened when the molecular weight of CSPs reached 3.5 and $2 \mathrm{kDa}$. CSP3 with a molecular weight of $6.0 \mathrm{kDa}$ exhibited the strongest antioxidant activity. After protection with $60 \mu \mathrm{g} / \mathrm{mL}$ CSPs, the viability of human renal proximal tubular epithelial cells (HK-2) damaged by nano-COM crystals increased, the level of reactive oxygen species decreased, and the amount of COM crystal adhered onto the cell surface decreased. The ability of CSPs to protect cells from CaOx crystal damage was consistent with their antioxidant activity. CSPs can specifically combine with CaOx crystal to inhibit the conversion of calcium oxalate dihydrate crystal to calcium oxalate monohydrate crystal. All these results showed that the activity of CSPs was closely correlated with molecular weight. A very high or low molecular weight of CSPs was not conducive to their activity. CSPs, especially CSP3 with a molecular weight of $6.0 \mathrm{kDa}$, can be used as a potential antistone drug.

\section{Introduction}

Kidney stone is a common disease that affects $10 \%$ to $15 \%$ of the population and has a high recurrence rate [1]. At present, no effective method has been developed to prevent kidney stone formation and delay its recurrence. The components of kidney stones are primarily calcium oxalate $(\mathrm{CaOx})$, including calcium oxalate monohydrate $(\mathrm{COM})$ and calcium oxalate dihydrate (COD) [2].

The formation of kidney stones is closely correlated to the heterogeneous nucleation, growth, and aggregation of minerals and the adhesion of crystals onto renal epithelial cells caused by urine supersaturation [3]. Renal epithelial cell injury aggravates the risk of kidney stone formation [4].
However, when the damaged renal epithelial cells are repaired [5] or the cells are preprotected [6], the probability of kidney stone formation can be greatly reduced. Exogenous plant polysaccharides with antioxidant function can effectively preprotect cells [7] and improve the ability of cells to resist oxidative damage.

Plant polysaccharides can also regulate the growth of $\mathrm{CaOx}$ crystals and inhibit the adhesion of crystals onto renal epithelial cells [6]. Gomes et al. [8] investigated the antiurolithic ability of sulfated seaweed polysaccharide (SP) and found that SP can change the surface charge of crystal, induce the morphology of $\mathrm{CaOx}$ crystal to become round and blunt, and reduce the crystal size. Huang et al. [9] explored the effects of five kinds of plant polysaccharides with different 
carboxyl contents on the growth of $\mathrm{CaOx}$ crystals. The results showed that five kinds of plant polysaccharides can inhibit the growth of COM, induce the formation of COD, and reduce the aggregation of crystals. At the same time, polysaccharides with higher carboxyl contents showed excellent crystal control ability.

Plant polysaccharides have biocompatibility, biodegradability, nontoxicity, and some specific therapeutic activities $[10,11]$. The biological activity of a polysaccharide primarily depends on its molecular weight, and type and content of acidic groups [12].

Corn silk is considered as a traditional natural medicine and functional food in the United States, China, Turkey, France, and other countries. Corn silk has antioxidant, antidiabetic, and antitumor activities $[13,14]$. Corn silk polysaccharide (CSP) is the most important component of corn silk [12]. Guo et al. [15] found that CSP has the ability to scavenge DPPH and hydroxyl radicals and can protect L6 skeletal muscle cells from $\mathrm{H}_{2} \mathrm{O}_{2}$-induced oxidative damage. Zhao et al. [16] showed that no symptoms, such as mortality and toxicity, were observed in CSP-treated mice, and CSP can significantly prolong the antifatigue time of mice.

Natural CSPs have difficulty crossing cell membrane and entering cells to play a role because of their large molecular weight $[5,17,18]$. Degradation of CSPs with large molecular weight can better exert their biological activities. The ultrasonic method is used to degrade CSP. In this method, because no reagent is added, the degraded product is easier to purify and has the advantages of environmental protection, convenience, and high efficiency $[19,20]$.

Hence, natural corn silk polysaccharide (CSP0) with molecular weight of $124 \mathrm{kDa}$ was degraded by ultrasonic wave, and five degraded polysaccharides with molecular weight of 2.0 to $26.1 \mathrm{kDa}$ were obtained. The antioxidant activity, protective ability to $\mathrm{HK}-2$ cells, and regulation ability to $\mathrm{CaOx}$ crystals of each CSP were compared and examined, hoping to provide experimental basis for further exploring the formation mechanism of kidney stones and developing new antistone drugs.

\section{Materials and Methods}

2.1. Materials and Apparatus. Corn silk polysaccharide (CSP0) was produced by Shaanxi Ciyuan Biological Company. Human kidney proximal tubular epithelial (HK-2) cells were purchased from Shanghai Cell Bank, Chinese Academy of Sciences (Shanghai, China). Calcium oxalate monohydrate $(\mathrm{COM})$ with a size of about $100 \mathrm{~nm}$ was synthesized according to the previous reference [21].

Fetal bovine serum and DMEM-F12 culture medium were purchased from HyClone Biochemical Products Co. Ltd. (Beijing, China). Cell proliferation assay kit (CCK-8) was purchased from Dojindo Laboratory (Kumamoto, Japan). Reactive oxygen detection kit (DCFH-DA) and rabbit anti-rat (FITC-IgG) were all purchased from Shanghai Beyotime Bio-Tech Co., Ltd. (Shanghai, China). Phosphatebuffered solution (PBS), phenazine, 1,1-diphenyl-2-picrylhydrazyl (DPPH), phenanthroline and other conventional reagents were of analytical grade and were purchased from
Guangzhou Chemical Reagent Company (Guangzhou, China).

Apparatuses that were used are as follows: Fouriertransform infrared spectrometer (FT-IR, Nicolet, American), nuclear magnetic resonance (Varian Bruker-500 MHz, Bruker, Germangy), ultrasonic apparatus (aligned with JP-100S), Ubbelohde capillary viscometer (0.4-0.5, Qihang Glass Instrument Factory, Shanghai, China), thermogravimetric analyzer (TGA/DSC 3+, Mettler Toledo, USA), the apparatus included D/max $2400 \mathrm{X}$-ray powder diffractometer (Rigaku, Japan), field emission scanning electron microscope (ULTRA55, Zeiss, Germany), and OPTIMA-2000DV inductively coupled plasma (ICP) (ICP-AES, Optima 2000DV, PerkinElmer, CT, USA, Zetasizer nano ZS90, fluorescence microscope (IX51, OLYMPUS, Japan), flow cytometry (FACS Aria, BD Company, USA), and enzyme mark instrument (SafireZ, Tecan, Switzerland).

\subsection{Degradation of CSP and Characterization}

(1) Degradation. Using ultrasonic technology, CSP0 with a molecular weight of $124 \mathrm{kDa}$ was degraded at room temperature for different time (Table 1). CSP0 was dissolved in distilled water at $5 \mathrm{mg} / \mathrm{mL}$ and ultrasonic frequency was $600 \mathrm{~W}, 40 \mathrm{kHz}$. After ultrasonic treatment, the degraded solution was then concentrated to one-third of its original volume at $60^{\circ} \mathrm{C}$. The product was precipitated by three times addition of anhydrous ethanol [19]. The solution was stored overnight and then filtered, then washed with anhydrous ethanol twice. The degraded polysaccharide (CSPs) was obtained by drying in vacuum.

(2) Measurement of Molecular Weights of CSPs. According to the literature [17], the molecular weight of polysaccharide was determined by Ubbelohde viscosity method. The relationship between intrinsic viscosity $[\eta]$ and the molecular weight $M$ of CSPs could be described by the Mark-Houwink empirical equation $\eta=\kappa M^{\alpha}$. For CSP: $\kappa=0.0288$, $\alpha=0.5[12,17]$. The final value is the average of three parallel experiments.

(3) Determination of Carboxyl (-COOH) Content in CSPs. $\mathrm{COOH}$ content of CSPs was determined by the method of conductometric titration [22]. Each experiment was repeated three times and averaged.

(4) FT-IR Characterization of CSPs. FT-IR spectra of polysaccharides were determined using films prepared by $2.0 \mathrm{mg}$ of dry CSP sample and $200 \mathrm{mg} \mathrm{KBr}$ in the wavenumber range of $4000-400 \mathrm{~cm}^{-1}$.

(5) ${ }^{1} \mathrm{H}$ and ${ }^{13} \mathrm{C}$ NMR Characterization of CSPs. According to reference [23], approximately $20 \mathrm{mg}$ of dry CSP sample was dissolved in $0.5 \mathrm{~mL}$ of deuterated water $\left(\mathrm{D}_{2} \mathrm{O}\right)$ in NMR tube. After completely dissolved, the polysaccharide sample is put into a magnetic field of a nuclear magnetic resonance spectrometer for detection. 
TABle 1: Degradation conditions and basic physicochemical properties of CSPs with different molecular weights.

\begin{tabular}{lcccc}
\hline CSPs & $\begin{array}{c}\text { Ultrasonic } \\
\text { degradation } \\
\text { time* }(\mathrm{min})\end{array}$ & $\begin{array}{c}\text { Intrinsic } \\
\text { viscosity }[\eta] \\
(\mathrm{mL} / \mathrm{g})\end{array}$ & $\begin{array}{c}\text { Mean } \\
\text { molecular } \\
\text { weights } \\
\mathrm{Mr}(\mathrm{kDa})\end{array}$ & $\begin{array}{c}\text { Uronic acid } \\
\text { content }(\%)\end{array}$ \\
\hline CSP0 & 0 & $9.35 \pm 3.54$ & 124 & 19.6 \\
CSP1 & 15 & $4.55 \pm 0.94$ & 26.1 & 26.8 \\
CSP2 & 17 & $3.19 \pm 0.33$ & 12.2 & 29.6 \\
CSP3 & 20 & $2.29 \pm 0.3$ & 6.0 & 31.3 \\
CSP4 & 27 & $1.67 \pm 0.3$ & 3.5 & 28.0 \\
CSP5 & 30 & $1.3 \pm 0.7$ & 2.0 & 25.6 \\
\hline
\end{tabular}

${ }^{*}$ Ultrasonic power: $600 \mathrm{~W}$; ultrasonic frequency: $40 \mathrm{kHz}$.

\subsection{Antioxidant Activity Detection of Corn Silk Polysaccharides}

(1) Hydroxyl Radical (·OH) Scavenging Capacity [24]. The $\cdot \mathrm{OH}$ scavenging ability of polysaccharide in vitro was detected by $\mathrm{H}_{2} \mathrm{O}_{2} / \mathrm{Fe}$ system method.

(2) DPPH Radical Scavenging Capacity [25]. $3 \mathrm{~mL}$ CSP with different molecular weights $(0.15-3 \mathrm{mg} / \mathrm{mL})$ was mixed with DPPH $(0.4 \mathrm{mmol} / \mathrm{L}, 1 \mathrm{~mL})$. The mixture was incubated in the dark at $37^{\circ} \mathrm{C}$ for $30 \mathrm{~min}$. The absorbance is detected at $517 \mathrm{~nm}$ to reflect the DPPH radical scavenging ability of polysaccharide.

(3) Reducing Power [26]. 2.5 mL CSP with different molecular weight $(0.15-3.0 \mathrm{mg} / \mathrm{mL})$ was mixed with $2 \mathrm{~mL}$ phosphate buffer (PBS, $\mathrm{pH}=6.6$ ) and $2.5 \mathrm{~mL}$ $1 \% \mathrm{~K}_{3}\left[\mathrm{Fe}(\mathrm{CN})_{6}\right]$. The mixture was incubated at $50^{\circ} \mathrm{C}$ for $30 \mathrm{~min} .2 .5 \mathrm{~mL} 10 \%$ trichloroacetic acid was added to the mixture which was then centrifuged for $10 \mathrm{~min}$ at $3000 \mathrm{r} / \mathrm{min}$. The supernatant $(2.5 \mathrm{~mL})$ was mixed with $0.5 \mathrm{~mL} \mathrm{FeCl}_{3} \cdot 6 \mathrm{H}_{2} \mathrm{O}(0.1 \%, w / v)$ solution and $5 \mathrm{~mL}$ distilled water. The solution was mixed fully and left to stand for $10 \mathrm{~min}$. Then, the absorbance was measured at $700 \mathrm{~nm}$.

(4) Ferrous Ion-Chelating Capacity [27]. $1 \mathrm{~mL}$ CSP with different molecular weights $(0.15-3.0 \mathrm{mg} / \mathrm{mL})$ was mixed with $2.25 \mathrm{~mL}$ distilled water and $0.05 \mathrm{~mL}$ $2.0 \mathrm{mmol} / \mathrm{L}$ ferrous chloride solution, respectively, and the reaction lasts for $30 \mathrm{~s}$. Next, the solutions were mixed with $0.2 \mathrm{~mL}$ phenazine $(5.0 \mathrm{mmol} / \mathrm{L})$ and reacted at room temperature for $10 \mathrm{~min}$, and the absorbance of the mixture was measured at $562 \mathrm{~nm}$. EDTA-2Na was used as the positive control group.

\subsection{Regulation of Calcium Oxalate Crystal Growth by Corn Silk Polysaccharides}

(1) Calcium Oxalate Crystal Synthesis. CaOx metastable solution was prepared in a $50 \mathrm{~mL}$ volumetric flask by adding $3.0 \mathrm{~mL}$ of $10 \mathrm{mmol} / \mathrm{L} \mathrm{CaCl}, 1 \mathrm{~mL}$ of $0.50 \mathrm{~mol} / \mathrm{L} \mathrm{NaCl}$, and a final concentration of
$0.5 \mathrm{mg} / \mathrm{mL}$ CSP. Distilled water was added to about $46 \mathrm{~mL}$ and $3.0 \mathrm{~mL}$ of $10 \mathrm{mmol} / \mathrm{L} \mathrm{Na}_{2} \mathrm{Ox}$ was added. The volume of the solution was diluted to scale with distilled water. The crystal was filtered by $0.22 \mu \mathrm{m}$ microporous membrane. The solution obtained was $\mathrm{c}\left(\mathrm{Ca}^{2+}\right)=\mathrm{c}\left(\mathrm{Ox}^{2}-\right)=0.60 \mathrm{mmol} / \mathrm{L}$ and $\mathrm{c}(\mathrm{NaCl})=$ $10 \mathrm{mmol} / \mathrm{L}[28,29]$. The $\mathrm{CaOx}$ solution was poured into a $50 \mathrm{~mL}$ beaker for crystallization, and a clean glass slide was placed at the bottom of the beaker. To prevent supersaturation of the system due to volatilization of solvent water from driving crystal formation, crystal growth was performed under static conditions. After the crystal grew for $3 \mathrm{~d}$, the substrate was removed and dried in a dryer. The concentration of soluble $\mathrm{Ca}^{2+}$ ions in the supernatant was measured through inductively coupled plasma (ICP) emission spectrometry.

(2) Characterization of Crystal Structure. The abovesynthesized $\mathrm{CaOx}$ crystals were characterized by FT-IR, SEM, and X-ray diffraction. Dried CaOx sample $(2.0 \mathrm{mg})$ was mixed with $\mathrm{KBr}(200 \mathrm{mg})$, then grinding with agate mortar, tableting, and scanning with infrared spectrometer in the wavenumber range of $4000-400 \mathrm{~cm}^{-1}$. The synthesized crystals were analyzed in an X-ray diffractometer under the test conditions of $\mathrm{CuK} \alpha$ ray, graphite monochromator, $30 \mathrm{kV}$, $25 \mathrm{~mA}$, scanning range of $5-60^{\circ}$, scanning speed of $8 \% \mathrm{~min}$, and step width of $0.02 \%$ for qualitative and quantitative analysis. The samples were treated with gold spray and observed under a field emission scanning electron microscope for morphology analysis.

The relative percentage contents of COM and COD in the $\mathrm{CaOx}$ precipitates were calculated through the $K$ value method and the relative percentage contents of COD:

$$
\mathrm{COD} \%=\frac{I_{\mathrm{COD}}}{I_{\mathrm{COM}}+I_{\mathrm{COD}}} \times 100 \% \text {, }
$$

where $I_{\mathrm{COM}}$ and $I_{\mathrm{COD}}$ are the intensities of the spacing (101) of COM and (200) of COD crystals.

(3) Zeta Potential Determination of Crystal Surface. $\mathrm{CaOx}$ crystals $(1 \mathrm{mg})$ were dispersed in $3.0 \mathrm{~mL}$ of double distilled water. After ultrasonication for $10 \mathrm{~min}$, the zeta potential was detected with a Zetasizer Nano ZS90 apparatus at $25^{\circ} \mathrm{C}$.

(4) Thermal Stability Characterization of Crystals. According to Reference [30], the thermostability of $\mathrm{CaOx}$ crystals was investigated by thermogravimetric analysis on Mettler Toledo thermal analyzer under nitrogen atmosphere from $25^{\circ} \mathrm{C}$ to $900^{\circ} \mathrm{C}$ at a heating rate $10^{\circ} \mathrm{C} / \mathrm{min}$.

(5) Effect of Polysaccharides on Crystallization Kinetics of Calcium Oxalate Crystals. The solutions were prepared at concentrations of $1 \times 10^{-1}, 1 \times 10^{-2}, 1 \times$ 
$10^{-3}, 1 \times 10^{-4}$, and $1 \times 10^{-5} \mathrm{~mol} / \mathrm{L} \mathrm{CaCl}_{2}$. The calcium ion-selective electrode was selected as the negative electrode of the $\mathrm{pH}$ acidometer. The calomel electrode was used as the positive electrode of the $\mathrm{pH}$ acidity meter. Two electrodes were inserted into the above solution, and the potential values $(E)$ at different concentrations were read out from diluted to concentrated by the $\mathrm{pH}$ acidity meter. $\mathrm{LgC}$ is plotted on the abscissa $(x)$, and $E$ is plotted on the ordinate $(y)$, and the linear regression equation is obtained.

The prepared $\mathrm{CaOx}$ metastable solution was placed in a $50 \mathrm{~mL}$ beaker, the concentration of $\mathrm{Ca}^{2+}$ in the solution was detected by using an ion-selective electrode, and the inhibition percentage of CSP on $\mathrm{CaOx}$ crystallization was calculated according to the inhibition ratio $=\left(1-r_{\text {inhibitor }} /\right.$ $\left.r_{\text {control }}\right) \times 100 \%$ [29].

2.5. Cytotoxicity Measurement of Corn Silk Polysaccharides on HK-2 Cells. Because CSP0 has a large molecular weight $(124 \mathrm{kDa})$ and is not easy to enter cells [22], we chose CSP1, CSP2, CSP3, CSP4, and CSP5 for the subsequent cell tests.

Cell suspension with a cell concentration of $1.0 \times 10^{5}$ cells $/ \mathrm{mL}$ and $100 \mu \mathrm{L} /$ well was inoculated per well in 96-well plates and incubated in an incubator in a $5 \% \mathrm{CO}_{2}$ environment at $37^{\circ} \mathrm{C}$ for $24 \mathrm{~h}$. Cells were confluent into monolayers and incubated in serum-free DMEM medium for $12 \mathrm{~h}$; the culture solution was discarded. And then $0.1 \mathrm{~mL}$ of 60 and $100 \mu \mathrm{g} / \mathrm{mL}$ CSPs with various molecular weights were added and each concentration was repeated in five parallel wells. At the same time, the cell control group (polysaccharide concentration: $0 \mu \mathrm{g} / \mathrm{mL}$ ) was set up. After incubation for $24 \mathrm{~h}$, the OD value was measured by using the enzyme mark instrument at $450 \mathrm{~nm}$ according to the CCK-8 kit instruction.

\subsection{Polysaccharides Protect HK-2 Cells from Damage by Nano-COM Crystals}

(1) Cell Viability Detection by CCK-8. After cells were confluent into monolayer, the experiment was divided into 3 groups: (1) the normal control group: in which only serum-free culture medium was added; (2) the damaged group: in which serum-free culture medium with $200 \mu \mathrm{g} / \mathrm{mL}$ COM was added and incubated for $12 \mathrm{~h}$; and (3) the protection group: CSPs with different molecular weights of $20,40,60,80$, and $100 \mu \mathrm{g} / \mathrm{mL}$ were mixed with $200 \mu \mathrm{g} / \mathrm{mL}$ COM for $15 \mathrm{~min}$ and then cocultured with cells for $12 \mathrm{~h}$. Five multiple wells were set up for each experiment. The OD value was measured by using the enzyme mark instrument at $450 \mathrm{~nm}$ according to the CCK- 8 kit instruction.

(2) Reactive Oxygen Species (ROS) Level Detection. $1.0 \mathrm{~mL}$ of cells suspension with a concentration of $1.0 \times 10^{5} \mathrm{cell} / \mathrm{s} / \mathrm{mL}$ was inoculated per well in 12 -well plates. The cells were divided into three groups: (1) the normal control group: in which only serum-free culture medium was added; (2) the damaged group: in which serum-free culture medium containing
$200 \mu \mathrm{g} / \mathrm{mL}$ COM was added and incubated for $12 \mathrm{~h}$; and (3) the protection group: CSPs with different molecular weights of $60 \mu \mathrm{g} / \mathrm{mL}$ were mixed with $200 \mu \mathrm{g} / \mathrm{mL} \mathrm{COM}$ for $15 \mathrm{~min}$ and then cocultured with cells for $12 \mathrm{~h}$. The cells were added diluted DCFH-DA and incubated for $30 \mathrm{~min}$ at $37^{\circ} \mathrm{C}$. Then, the cells were washed 3 times with PBS. The fluorescence intensity was observed under a fluorescence microscope.

(3) Quantitative Analysis of the Proportion of Cells with Adhered Crystals. $1.0 \mathrm{~mL}$ of cells suspension with a concentration of $1.0 \times 10^{5}$ cells $/ \mathrm{mL}$ was inoculated per well in 12-well plates. The cells were divided into two groups: (a) the COM damaged group: in which serum-free culture medium with $200 \mu \mathrm{g} / \mathrm{mL}$ FITClabeled nano-COM crystals was added and incubated for $12 \mathrm{~h}$; (b) the protection group: CSPs with different molecular weights of $60 \mu \mathrm{g} / \mathrm{mL}$ were mixed with $200 \mu \mathrm{g} / \mathrm{mL}$ FITC-labeled nano-COM for $15 \mathrm{~min}$ and then cocultured with cells for $12 \mathrm{~h}$. The 12 -well plate was precooled for $30 \mathrm{~min}$ at $4^{\circ} \mathrm{C}$, and then $200 \mu \mathrm{g} / \mathrm{mL}$ FITC-labeled nano-COM crystals were added. The cells were cultured at $4^{\circ} \mathrm{C}$ for $1 \mathrm{~h}$ to inhibit cell endocytosis. After $12 \mathrm{~h}$ at $4^{\circ} \mathrm{C}$, the cells were washed twice with cold PBS, PBS resuspended cells after pancreatin digestion, and the proportion of cells with adhered crystals was detected by flow cytometry.

2.7. Statistical Analysis. Experimental data were expressed by the mean \pm standard deviation $(\bar{x} \pm \mathrm{SD})$. The experimental results were analyzed statistically using SPSS 13.0 software. The differences of means between the experimental groups and the control group were analyzed by Tukey. If $P<0.05$, there was significant difference; if $P<0.01$, the difference was extremely significant; if $P>0.05$, there was no significant difference.

\section{Results}

3.1. Degradation of Corn Silk Polysaccharide and Determination of - $\mathrm{COOH}$ Content. After degradation of $124 \mathrm{kDa}$ corn silk polysaccharide CSP0 at different times with reference to the conditions in Table 1, five degraded polysaccharides, namely, CSP1, CSP2, CSP3, CSP4, and CSP5, with molecular weights of $26.1,12.2,6.0,3.5$, and $2.0 \mathrm{kDa}$, were obtained, respectively. With prolonged ultrasonic time, the molecular weight of the polysaccharide decreased, the solubility of the polysaccharide increased, and the viscosity decreased. These behaviors can enhance the biological activity of polysaccharide [20].

The content of - $\mathrm{COOH}$ in the six CSPs was determined by conductometric titration and converted into uronic acid content. After degradation, the uronic acid content of polysaccharide $(25.6 \%$ to $31.3 \%)$ was higher than that of CSP0 (19.6\%), and CSP3 with molecular weight of $6.0 \mathrm{kDa}$ was the highest $(31.3 \%)$; when the molecular weight was lower than or higher than $6.0 \mathrm{kDa}$, the uronic acid content decreased. The uronic acid content of CSPs is basically consistent with the results reported in the literature $[15,31]$. 
3.2. FT-IR Characterization of CSPs. Figure 1(a) shows the FT-IR spectra of CSPs with different molecular weights. The wide absorption band at $3,423.3 \mathrm{~cm}^{-1}$ corresponds to the absorption peak of the stretching vibration of $-\mathrm{OH}$ in the polysaccharide. The absorption band at $2,933.6 \mathrm{~cm}^{-1}$ corresponds to the stretching vibration of $\mathrm{C}-\mathrm{H}$. The vibration absorption peaks at $1,637.8 \mathrm{~cm}^{-1}$ were $\mathrm{C}=\mathrm{O}$ and $\mathrm{C}=\mathrm{C}$. The peak at $1,379.5 \mathrm{~cm}^{-1}$ was a $\mathrm{C}-\mathrm{O}$ stretching peak. The absorption peaks at $1,080.1$ and $1,041.4 \mathrm{~cm}^{-1}$ indicated $\mathrm{C}-\mathrm{O}-\mathrm{H}$ stretching vibration in $-\mathrm{COOH}$ and $\mathrm{C}-\mathrm{O}-\mathrm{C}$ stretching vibration of ether bond in pyran ring [17, 32]. The peak at $1,080.1 \mathrm{~cm}^{-1}$ corresponds to galactan, and the peak at $1,041.4 \mathrm{~cm}^{-1}$ indicated arabinan side chains [32].

3.3. ${ }^{1} \mathrm{H}$ and ${ }^{13} \mathrm{C}$ NMR Characterizations of Corn Silk Polysaccharides. As shown in Figures 1(b) and 1(c), no significant change can be observed in the ${ }^{1} \mathrm{H}$ NMR spectrum of CSP3 after degradation and CSP0 before degradation, indicating that ultrasonic degradation did not destroy the structure of the polysaccharide.

In the ${ }^{1} \mathrm{H}$ NMR spectra of CSP0 and CSP3 (Figures 1(b) and $1(\mathrm{c})$ ), the signal peaks appearing in $\delta 3.16-5.31 \mathrm{ppm}$ are glycosidic bonds of CSPs. The signal peak at $\delta 2.35 \mathrm{ppm}$ is $\mathrm{CH}_{3}$ proton of acetyl ester. The signal peaks at $\delta 1.25 \mathrm{ppm}$ and $1.08 \mathrm{ppm}$ come from $\mathrm{CH}_{3}$ protons of deoxysugar. Methyl ester stroma was observed at $3.74 \mathrm{ppm}$ [32].

$\delta 5.16,4.24,4.09,3.81,3.57$, and $3.75 \mathrm{ppm}$ belong to the chemical shifts of H-1 to H-6 of -4,6)- $\alpha$-D-Glcp-(1; however, $\delta 5.16,4.09,4.03,3.59,3.55$, and $1.11 \mathrm{ppm}$ belong to the chemical shifts of H-1 to H-5 and $\mathrm{CH}_{3}$ of 3$)-\alpha$-L-Araf- $(1 ; \delta$ $5.26,3.75,3.55,3.59,3.75$, and $1.11 \mathrm{ppm}$ belong to the chemical shifts of H-1 to H-5 and $\mathrm{CH}_{3}$ of $\alpha$-L-Rhap- $(1 ; \delta 5.09$, $3.81,3.56,3.81,3.55$, and $3.59 \mathrm{ppm}$ belong to the chemical shifts of H-1 to H-6 of 4$)-\beta$-D-Galp- $(1 ; \delta 5.00,3.55,3.59$, $3.81,3.75$, and 3.18 ppm belong to the chemical shifts of $\mathrm{H}-$ 1 and H-6 of 3,5)- $\beta$-D-Manp- $(1 ; \delta 4.70,3.59,3.81,4.24$, and 4.09 ppm belong to the chemical shifts of $\mathrm{H}-1$ and $\mathrm{H}-5$ of $\beta$-D-Xylp-(1 [15]. The incomplete agreement with the hydrogen chemical shift on the standard monosaccharide may be due to the complex structure of the polysaccharides, and the interaction between groups changes the chemical shift of the hydrogen atom.

In the ${ }^{13} \mathrm{C}$ NMR spectra of CSP0 and CSP3 (Figures $1(\mathrm{~d})$ and $1(\mathrm{e}))$, the signal in the region of $\delta 100-104 \mathrm{ppm}$ indicates that the monosaccharide in the polysaccharide exists in the form of a pyran ring. The signal peak at $\delta 42.25 \mathrm{ppm}$ is designated as acetyl, and the signal at $\delta 53.26 \mathrm{ppm}$ is designated as methyl carbon and methoxy group of the ester group [16]. As shown in Figure $1(\mathrm{~d}), \delta 100.40,79.43,78.04,75.94,69.24$, and 60.45 ppm belong to C1 to C6 signal peaks of $-4,6)-\alpha$-DGlcp-(1, respectively; $\delta 109.01,81.74,83.80,70.25,71.17$, and 20.03 ppm correspond to the $\mathrm{C} 1$ to $\mathrm{C} 5$ and $\mathrm{CH}_{3}$ signal peaks of polysaccharide 3$)$ - $\alpha$-L-Araf-(1; however, $\delta 92.21,73.37$, $71.17,71.91,68.47$, and $16.77 \mathrm{ppm}$ belong to the C-1 to C-5 and $\mathrm{CH}_{3}$ signal peaks of $\alpha$-L-Rhap- $(1 ; \delta$ 107.48, 76.83, $73.37,75.62$, and 69.24 and $60.45 \mathrm{ppm}$ belong to the $\mathrm{C}-1$ to C-6 signal peaks of 4$)-\beta$-D-Galp- $(1 ; \delta$ 98.98, 71.52, 75.94, $68.47,73.37$, and 62.41 ppm belong to the C-1 and C- 6 signal peaks of 3,5)- $\beta$-D-Manp-(1; $\delta$ 107.48, 74.12, 76.83, 70.25, and $64.09 \mathrm{ppm}$ are attributed to the chemical shifts of $\mathrm{C}-1$ and C-5 on $\beta$-D-Xylp-(1 [15].

Based on the FT-IR, ${ }^{1} \mathrm{H}$, and ${ }^{13} \mathrm{C}$ NMR detection results, the CSPs in the present study primarily consist of $\alpha$-D-Glcp, $\alpha$-L-Araf, $\alpha$-L-Rhap, $\beta$-D-Galp, $\beta$-D-Manp, and $\beta$-D-Xylp, a result that is similar to that reported in literature $[16,33]$.

\subsection{Antioxidant Capacity of Corn Silk Polysaccharides with} Different Molecular Weights

(1) Scavenging Capacity of $\cdot \mathrm{OH}$ Radicals. The production of $\cdot \mathrm{OH}$ may lead to cell senescence and tissue damage [34]; thus, $\cdot \mathrm{OH}$ scavenging is an important characteristic of antioxidant defense mechanism. The $\cdot \mathrm{OH}$ scavenging capacity of the six CSPs is shown in Figure 2(a). The $\cdot \mathrm{OH}$ scavenging ability of three polysaccharides with intermediate molecular weights (namely, CSP2, CSP3, and CSP4) was greater than that of the polysaccharides with larger (namely, CSP0 and CSP1) and smaller molecular weights (namely, CSP5).

(2) DPPH Radical Scavenging Capacity. DPPH primarily exists in the form of nitrogen-containing free radicals and can accept single electron or hydrogen atom [25]. Therefore, the stability of DPPH radical is an important indicator to evaluate biological activity. Figure 2(b) shows that CSP3 with a molecular weight of $6.0 \mathrm{kDa}$ had the best $\mathrm{DPPH}$ radical scavenging ability. When the molecular weight of CSP was higher or lower than $6.0 \mathrm{kDa}$, the DPPH radical scavenging ability was reduced, and the crude polysaccharide CSP0 was the weakest.

(3) Reducing Power. The reducing ability of CSP2, CSP3, and CSP4 with intermediate molecular weights was stronger than that of the other polysaccharides (Figure 2(c)). The weakest reducing power was observed in CSP0 with the largest molecular weight.

(4) Chelating Effect on Ferrous Ions. Ferrous ions can cause Fenton reaction and free radical reaction and produce substances harmful to the human body [35]. Figure $2(\mathrm{~d})$ is a comparison of the ability of each CSP to chelate $\mathrm{Fe}^{2+}$. Among the CSPs, CSP3 had the strongest while CSP0 had the weakest chelating ability.

According to the four indexes in Figure 2, although the rules of polysaccharides are not completely consistent, CSP2, CSP3, and CSP4 had the strongest antioxidant capacity, whereas CSP0 and CSP5 had the weakest antioxidant capacity. Polysaccharides with intermediate molecular weights, especially CSP3, had the strongest antioxidant capacity, whereas CSP5 with the lowest molecular weight and CSP0 with the largest molecular weight were weaker. The antioxidant activity of polysaccharides increased gradually with the increase in polysaccharide concentration, showing concentrationdependent behavior.

3.5. Regulation of Corn Silk Polysaccharides on Calcium Oxalate Crystal Formation. The effects of six CSPs on the formation of $\mathrm{CaOx}$ crystals, the main component of kidney 


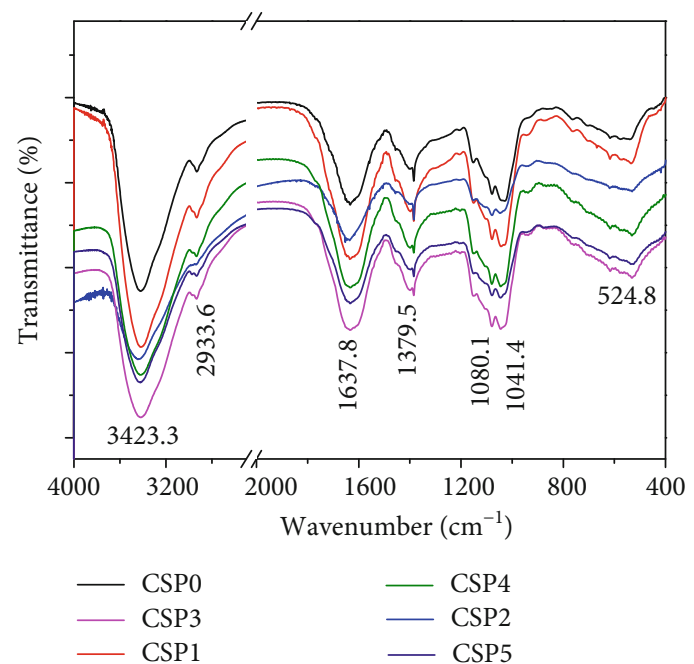

(a)

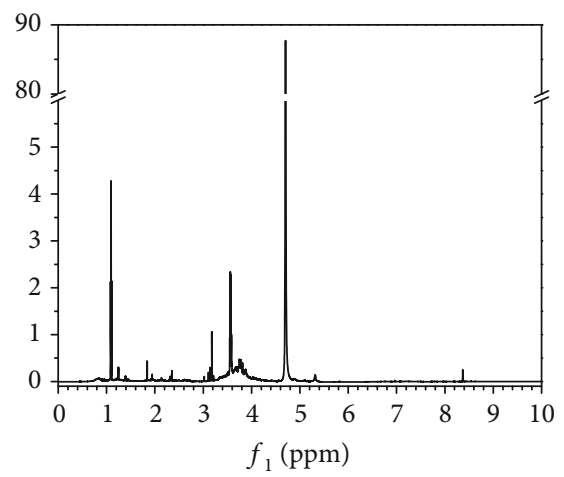

(b)

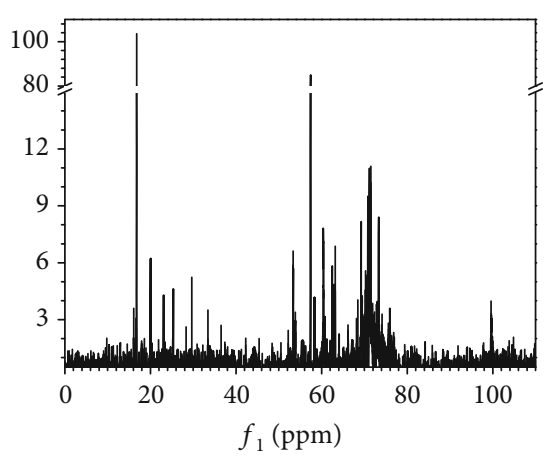

(d)

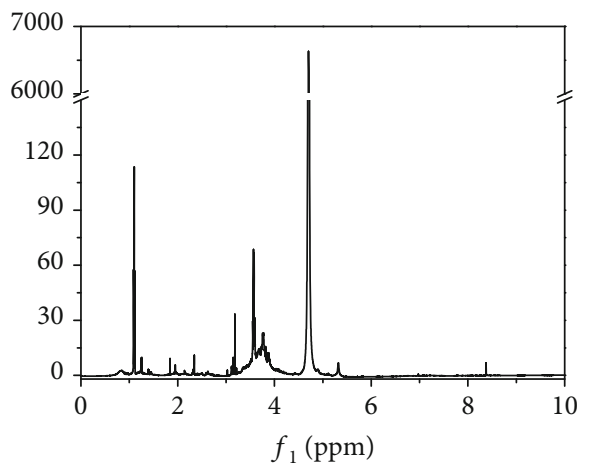

(c)

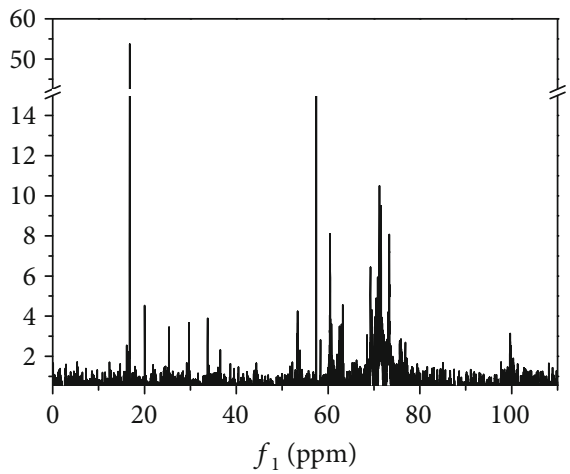

(e)

FIgURE 1: Structure characterization of CSPs. (a) FT-IR spectra of CSPs with different molecular weights. (b, c) ${ }^{1} \mathrm{H}$ NMR spectra of CSP0 and CSP3. (d, e) ${ }^{13} \mathrm{C}$ NMR spectra of CSP0 and CSP3.

stones, were compared. Figure 3(a) is the XRD patterns of $\mathrm{CaOx}$ crystal formed in the presence of $0.5 \mathrm{mg} / \mathrm{mL}$ CSPs. In the absence of polysaccharides, only diffraction peaks attributed to COM appeared, and the diffraction peaks at $2 \theta=$ $14.88^{\circ}, 24.2^{\circ}, 30.16^{\circ}$, and $38.24^{\circ}$ belong to the (101), (020), (202), and (130) planes of the COM crystal, respectively [36]. The addition of CSP can induce the formation of COD, and the diffraction peaks at $2 \theta=14.28^{\circ}, 30.12^{\circ}$, $32.28^{\circ}$, and $40.28^{\circ}$ belong to the (200), (211), (411), and (213) planes of the COD crystal, respectively [37].
Quantitative calculations showed that the percentage of COD $(73.1 \%$ to $84.1 \%)$ in the crystal induced by CSP initially increased and then decreased slightly (Figure 3(b)) as the molecular weight of CSP decreased; CSP3 with moderate molecular weight induced the highest percentage of COD (89.8\%), whereas CSP0 induced the lowest percentage of COD (61.0\%).

FT-IR detection consistently supported the aforementioned results (Figure 3(c)). In the absence of CSP, asymmetrical stretching $v_{\text {as }}\left(\mathrm{COO}^{-}\right)$and symmetrical stretching 


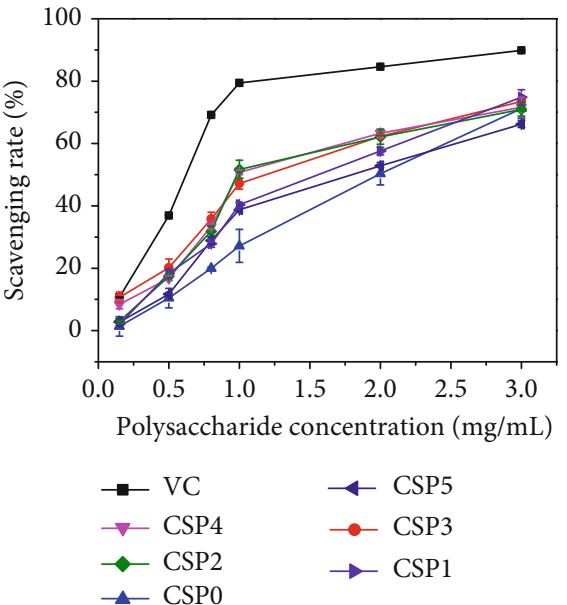

(a)

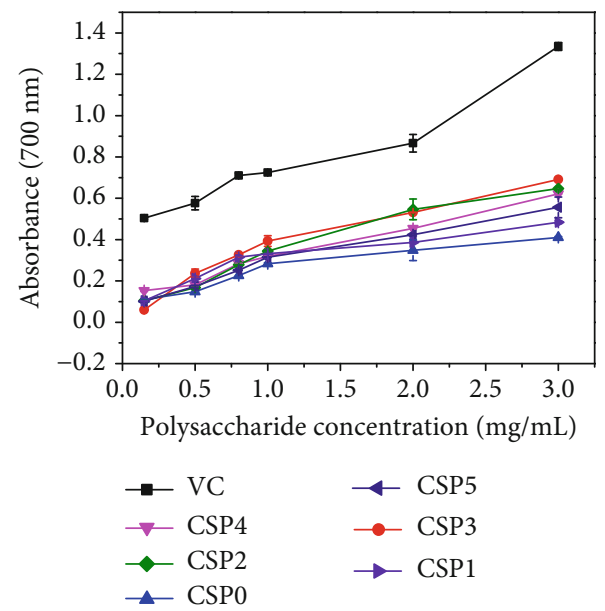

(c)

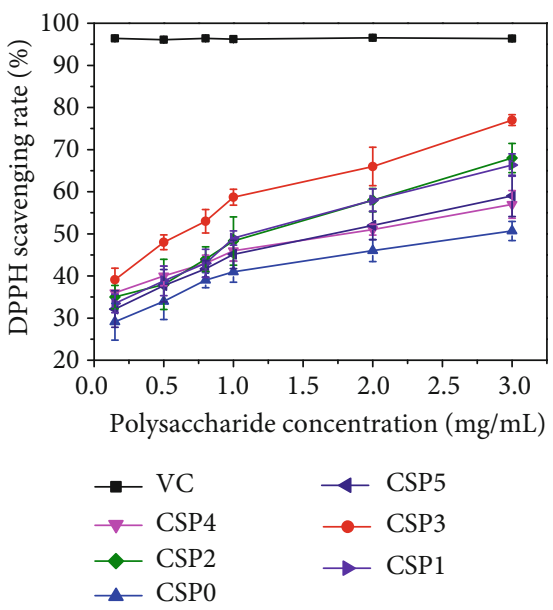

(b)

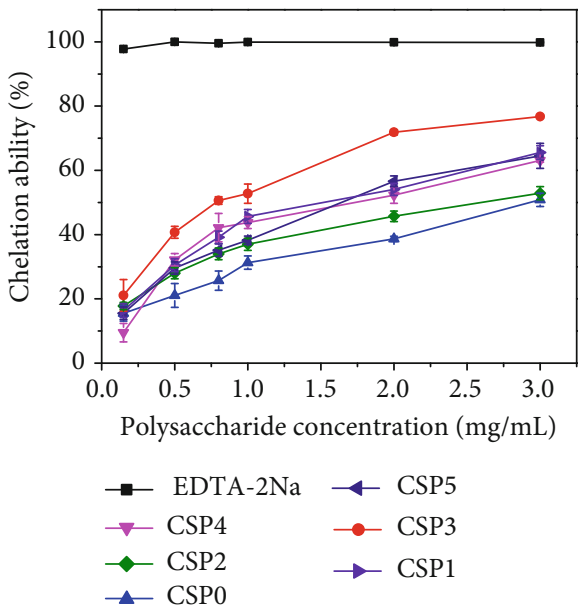

(d)

FIgURE 2: Antioxidant activities of CSPs with different molecular weights. (a) Hydroxyl radical scavenging capacity. (b) DPPH radical scavenging capacity. (c) Reducing power. (d) Chelating $\mathrm{Fe}^{2+}$ ion capacity.

$v_{\mathrm{s}}\left(\mathrm{COO}^{-}\right)$of $\mathrm{CaOx}$ appeared at 1,618 and $1,316 \mathrm{~cm}^{-1}$, respectively. At 3,490 to $3,059.2 \mathrm{~cm}^{-1}$, five stretching vibration peaks of $\mathrm{O}-\mathrm{H}$ bond appeared in the crystal water, indicating that the $\mathrm{CaOx}$ formed was pure COM crystal [36].

After CSP was added, $v_{\text {as }}(\mathrm{COO}-)$ and $v_{s}(\mathrm{COO}-)$ in the $\mathrm{CaOx}$ crystals all showed blue shift in different degrees as the molecular weight of CSPs decreased from 124 to $2.0 \mathrm{kDa}$ (Table 2). Varying blue shifts of $v_{\mathrm{as}}(\mathrm{COO}-)$ and $v_{\mathrm{s}}(\mathrm{COO}-)$ appeared at 1,618 to $1,653 \mathrm{~cm}^{-1}$ and 1,316 to $1,324 \mathrm{~cm}^{-1}$, respectively. This observation showed that the percentage of COM gradually decreased while COD gradually increased. Given that $v_{\text {as }}(\mathrm{COO}-)$ of COM and COD occur at 1,618 and $1,653 \mathrm{~cm}^{-1}$, respectively, $v_{\mathrm{s}}(\mathrm{COO}-)$ of COM and COD were 1,316 and $1,324 \mathrm{~cm}^{-1}$, respectively (Figure $3(\mathrm{~d}))[37,38]$. The blue shift values of $v_{\text {as }}(\mathrm{COO}-$ ) and $v_{s}(\mathrm{COO}-)$ depended on the percentage of COD crystals in the COM-COD mixture.

3.6. Effect of CSPO Concentration on Calcium Oxalate Crystal Formation. Increased polysaccharide concentration also increased its ability to induce COD formation. Figure 4(a) shows that the diffraction peaks of COD were strengthened as CSP0 concentration increased, suggesting an enhancement in the induced amount of COD. According to the quantitative calculation of $K$ value method [9], in the presence of CSP0 of $0.1,0.3,0.4,0.5,0.8$, and $1.0 \mathrm{mg} / \mathrm{mL}$, the percentage content of COD in the generated $\mathrm{CaOx}$ crystal was $0,8.6 \%$, $32.6 \%, 61.0 \%, 82.0 \%$, and 86.5\%, respectively (Figure 4(c)).

Figure 4(b) and Table 3 show the FT-IR spectra of $\mathrm{CaOx}$ crystal as CSP0 concentration increased, $v_{\text {as }}(\mathrm{COO}-)$ blue shift continuously. In the fingerprint region, the absorption bands of COD crystals were at 912 and $668 \mathrm{~cm}^{-1}$, which were obviously different from 951,887 , and $518 \mathrm{~cm}^{-1}$ of COM, of which 887 and $783 \mathrm{~cm}^{-1}$ belonged to the COM $\mathrm{C}-\mathrm{C}$ stretching vibration and $\mathrm{O}-\mathrm{C}-\mathrm{O}$ in-plane bending vibration, respectively [38].

3.7. Scanning Electron Microscopy Observation of Calcium Oxalate Crystals in the Presence of Corn Silk Polysaccharides. Figure 5 shows the scanning electron microscopy (SEM) observations of $\mathrm{CaOx}$ crystals formed in the presence of each CSPi. In the absence of polysaccharides, most of the crystals 


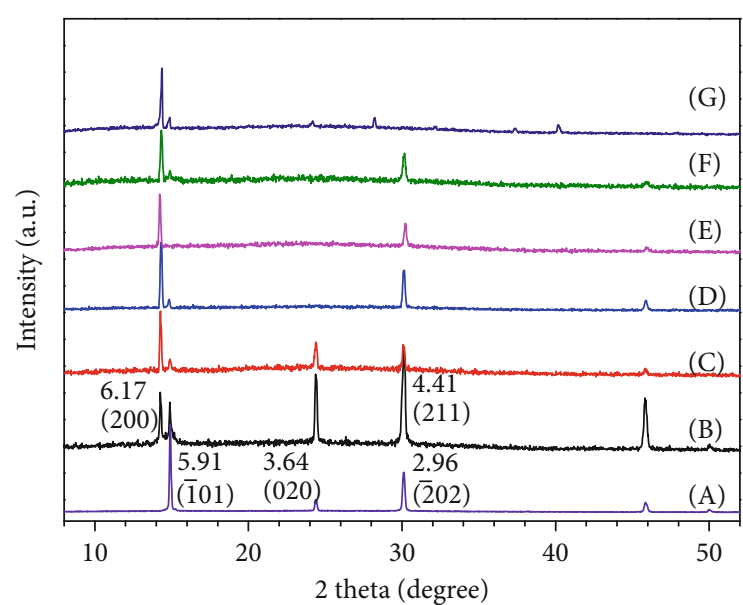

(a)

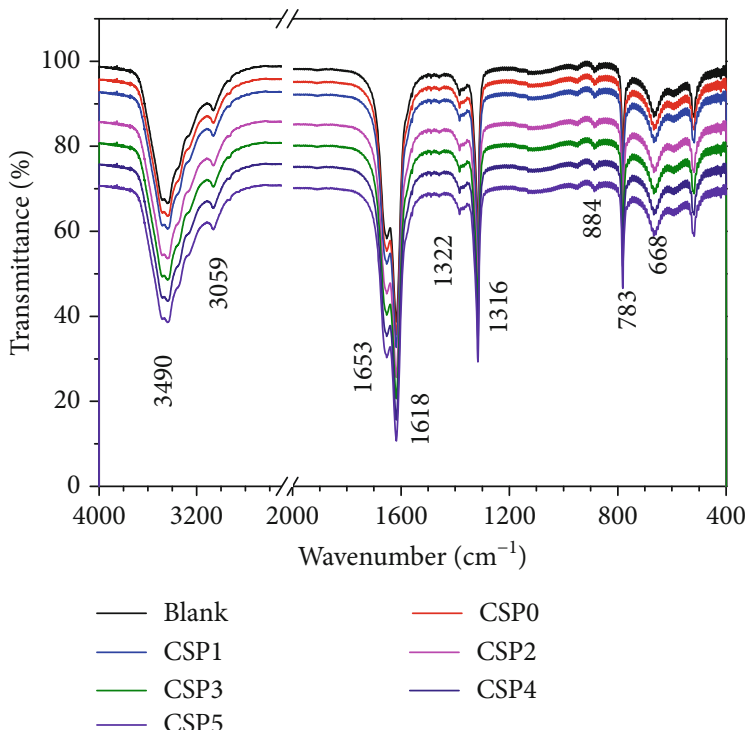

(c)

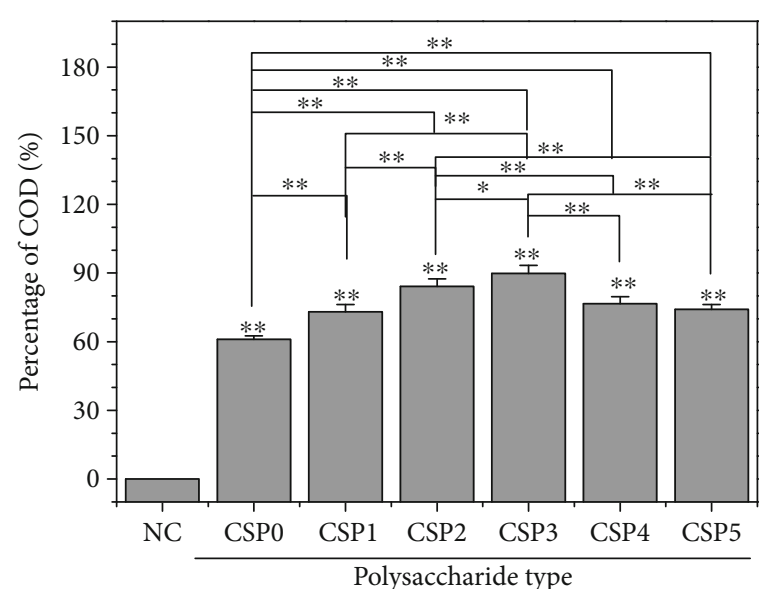

(b)

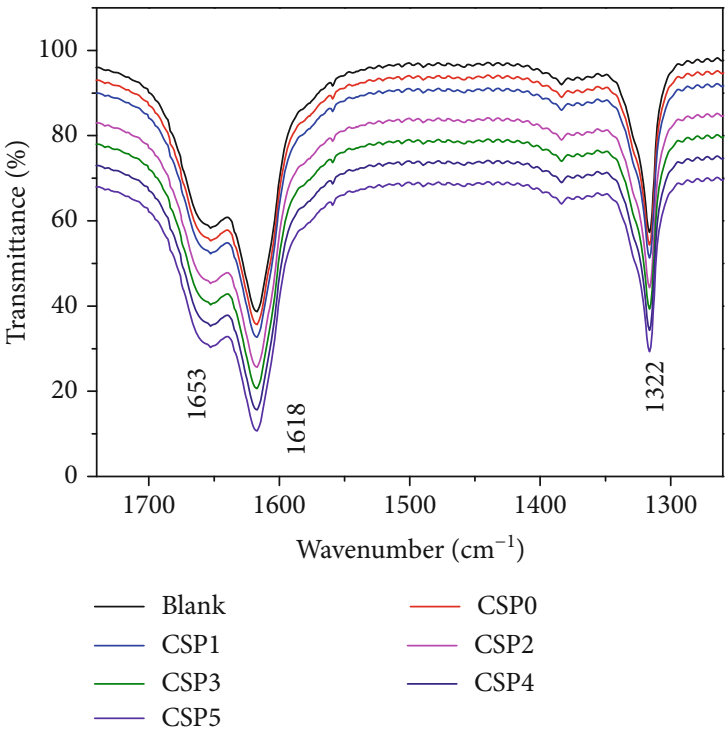

(d)

Figure 3: Characterization of CaOx formed in the presence of $0.5 \mathrm{mg} / \mathrm{mL}$ of CSPs. (a) XRD patterns: (A) blank control, (B) CSP0, (C) CSP1, (D) CSP2, (E) CSP3, (F) CSP4, (G) CSP5. (b) Percentage of COD in CaOx. (c, d) FT-IR spectra.

TABLE 2: FT-IR characteristic absorption peaks of CaOx crystals induced by CSPs with different molecular weights.

\begin{tabular}{|c|c|c|c|c|c|c|c|c|c|}
\hline CSPs & $\begin{array}{c}v_{\mathrm{as}}\left(\mathrm{COO}^{-}\right) \\
\left(\mathrm{cm}^{-1}\right)\end{array}$ & $\begin{array}{c}v_{\mathrm{as}}\left(\mathrm{COO}^{-}\right) \\
\left(\mathrm{cm}^{-1}\right)\end{array}$ & $\begin{array}{c}v_{s}\left(\mathrm{COO}^{-}\right) \\
\left(\mathrm{cm}^{-1}\right)\end{array}$ & $\operatorname{COM}\left(\mathrm{cm}^{-1}\right)$ & $\operatorname{COD}\left(\mathrm{cm}^{-1}\right)$ & $\operatorname{COM}\left(\mathrm{cm}^{-1}\right)$ & $\operatorname{COM}\left(\mathrm{cm}^{-1}\right)$ & $\operatorname{COD}\left(\mathrm{cm}^{-1}\right)$ & $\operatorname{COM}\left(\mathrm{cm}^{-1}\right)$ \\
\hline CSP0 & 1650.7 & 1618.0 & 1315.0 & 950 & & 886 & $783 \mathrm{sh}$ & 669 & 515 \\
\hline CSP1 & 1652.2 & 1625.2 & 1322.3 & 947 & & 885 & $783 \mathrm{sh}$ & 667 & 516 \\
\hline CSP2 & 1652.5 & 1625.2 & 1322.3 & 948 & 913 & 885 & 783 & 667 & 518 \\
\hline CSP3 & 1652.7 & 1631.1 & 1323.1 & 952 & 913 & 887 & 783 & 662 & 517 \\
\hline CSP4 & 1652.2 & 1631.8 & 1324.5 & 952 & 913 & & $783 \mathrm{sh}$ & 669 & 518 \\
\hline CSP5 & 1651.8 & 1631.8 & 1323.1 & & 912 & & $783 \mathrm{sh}$ & 663 & 518 \\
\hline $\begin{array}{l}\text { Pure } \\
\text { COD }\end{array}$ & 1653 & & 1324 & & 912 & & 783 & 668 & \\
\hline $\begin{array}{l}\text { Pure } \\
\text { COM }\end{array}$ & & 1618 & 1316 & 951 & & 887 & $783 \mathrm{sh}$ & & 518 \\
\hline
\end{tabular}



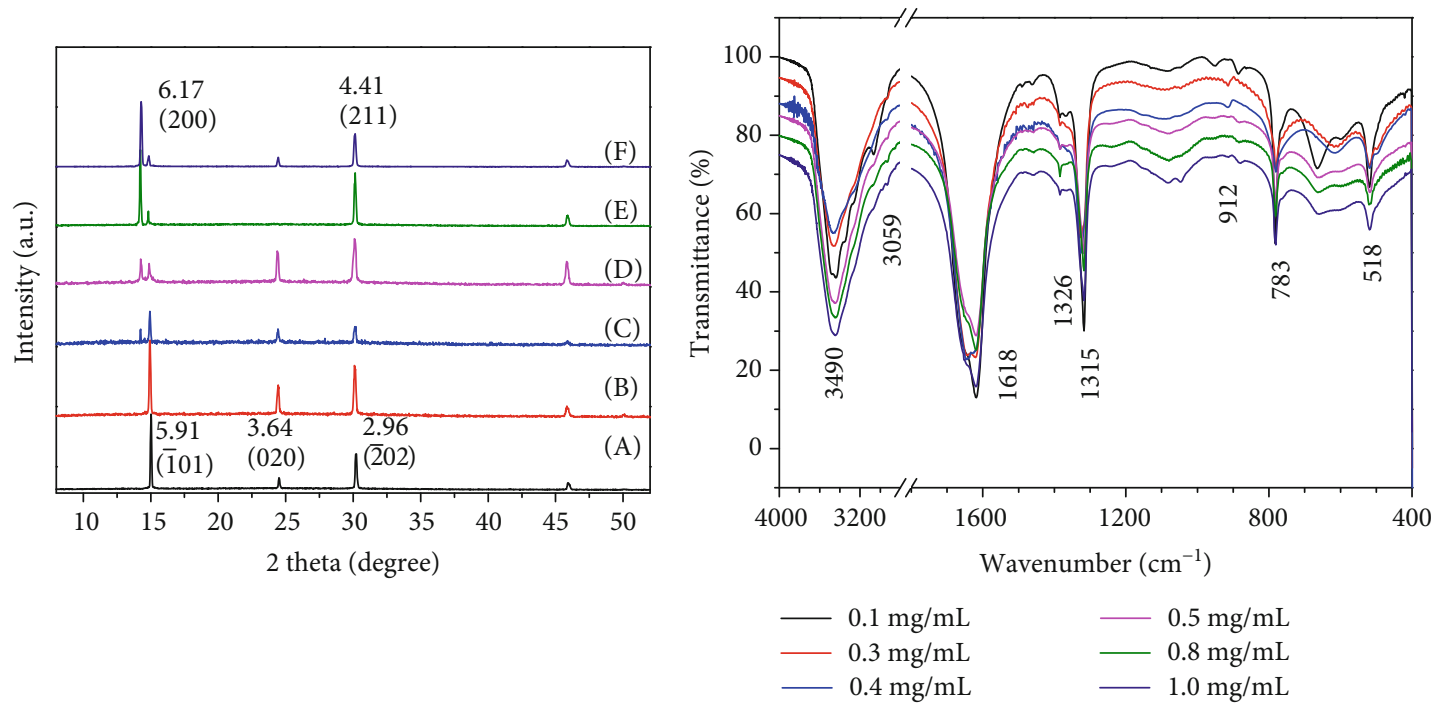

(a)

(b)

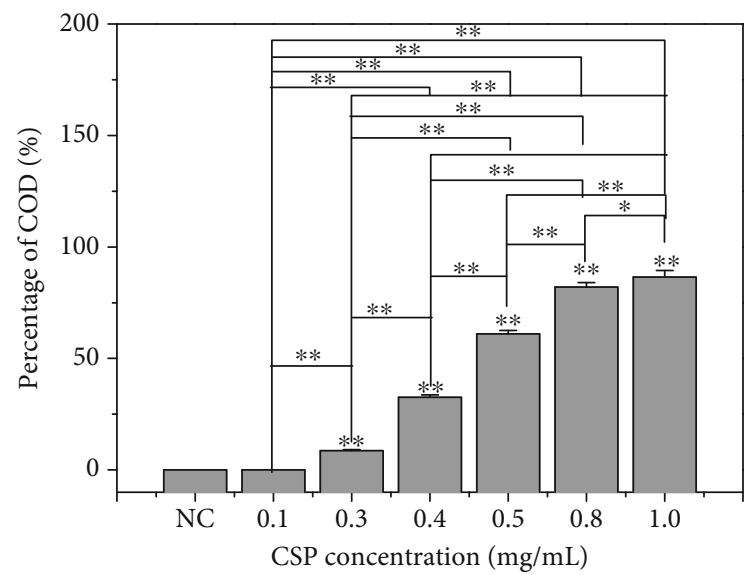

(c)

Figure 4: Characterization of CaOx crystals formed in the presence of different concentrations of CSP0. (a) XRD patterns: (A) 0.1, (B) 0.3, (C) 0.4, (D) 0.5, (E) 0.8, (F) $1.0 \mathrm{mg} / \mathrm{mL}$. (b) FT-IR spectra. (c) Percentage of COD in formed CaOx.

TABLE 3: FT-IR characteristic absorption peaks of CaOx crystals induced by different concentrations of CSP0.

\begin{tabular}{|c|c|c|c|c|c|c|c|c|c|}
\hline $\begin{array}{l}\text { Concentrations of } \\
\text { CSP0 }\end{array}$ & $\begin{array}{c}v_{\mathrm{as}}\left(\mathrm{COO}^{-}\right) \\
\left(\mathrm{cm}^{-1}\right)\end{array}$ & $\begin{array}{c}v_{\mathrm{as}}\left(\mathrm{COO}^{-}\right) \\
\left(\mathrm{cm}^{-1}\right)\end{array}$ & $\begin{array}{c}v_{\mathrm{s}}\left(\mathrm{COO}^{-}\right) \\
\left(\mathrm{cm}^{-1}\right)\end{array}$ & $\begin{array}{l}\mathrm{COM} \\
\left(\mathrm{cm}^{-1}\right) \\
\end{array}$ & $\begin{array}{l}\text { COD } \\
\left(\mathrm{cm}^{-1}\right) \\
\end{array}$ & $\begin{array}{l}\mathrm{COM} \\
\left(\mathrm{cm}^{-1}\right) \\
\end{array}$ & $\begin{array}{l}\mathrm{COM} \\
\left(\mathrm{cm}^{-1}\right) \\
\end{array}$ & $\begin{array}{l}\mathrm{COD} \\
\left(\mathrm{cm}^{-1}\right)\end{array}$ & $\begin{array}{l}\mathrm{COM} \\
\left(\mathrm{cm}^{-1}\right) \\
\end{array}$ \\
\hline 0.1 & 1642 & 1617.9 & 1315 & 951 & & 888 & $783 \mathrm{~s}$ & 665 & 515 \\
\hline 0.3 & 1646 & 1618.2 & 1315 & 950 & 912 & & $778 \mathrm{~s}$ & & 519 \\
\hline 0.4 & 1648.5 & 1618.2 & 1315 & 950 & 914 & & $783 \mathrm{~s}$ & & 517 \\
\hline 0.5 & 1650.7 & 1618.6 & 1319 & 950 & & 888 & $781 \mathrm{~s}$ & 662 & 518 \\
\hline 0.8 & 1652.5 & 1625.2 & 1323 & & & 883 & $781 \mathrm{sh}$ & 667 & 520 \\
\hline 1 & 1653 & 1626 & 1325 & & & 886 & & 668 & 519 \\
\hline Pure COD & 1653 & & 1328 & & 912 & & 783 & 668 & \\
\hline Pure COM & & 1618 & 1316 & 951 & & 887 & $783 \mathrm{sh}$ & & 518 \\
\hline
\end{tabular}

Note: s: strong; sh: sharp.

formed were hexagonal COM crystals and aggregation. After adding $0.5 \mathrm{mg} / \mathrm{mL}$ CSPi, tetragonal bipyramid COD crystals appeared. The percentage of COD increased first and then decreased slightly as the molecular weight of CSP decreased. SEM observation results consistently support the corresponding XRD and FT-IR results. 

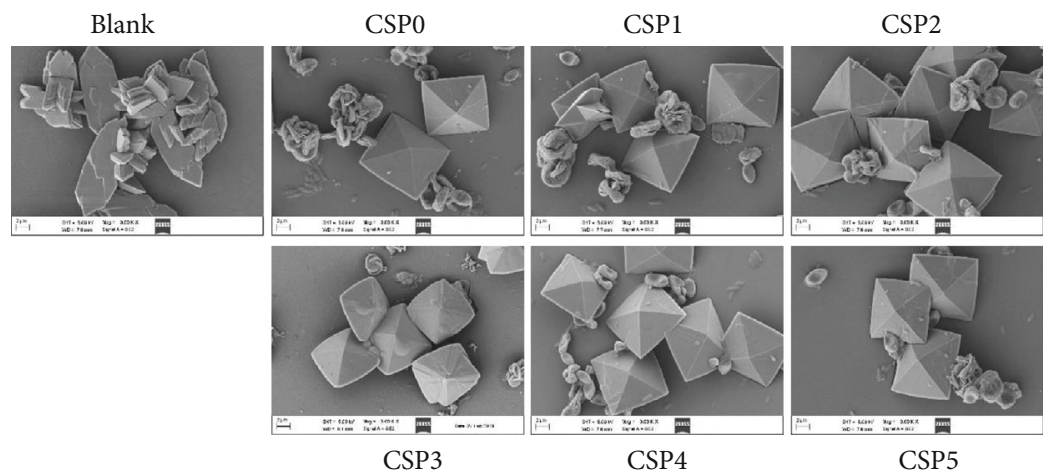

FIGURE 5: SEM images of CaOx crystals formed in the presence of $0.5 \mathrm{mg} / \mathrm{mL} \mathrm{CSPi.} \mathrm{c}\left(\mathrm{Ca}^{2+}\right)=\mathrm{c}\left(\mathrm{Ox}^{2-}\right)=0.60 \mathrm{mmol} / \mathrm{L}, \mathrm{c}(\mathrm{NaCl})=10 \mathrm{mmol} / \mathrm{L}$; crystal growth time: $3 \mathrm{~d}$. Magnification: 3000x.

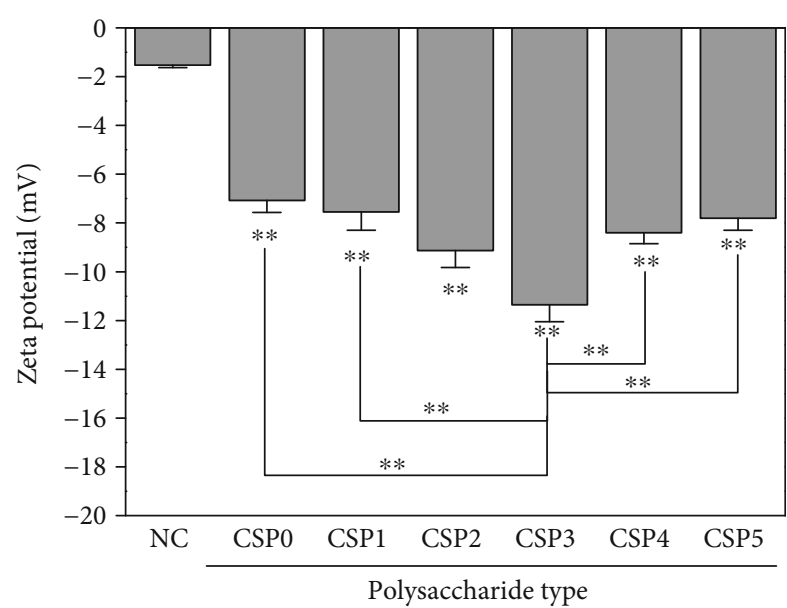

(a)

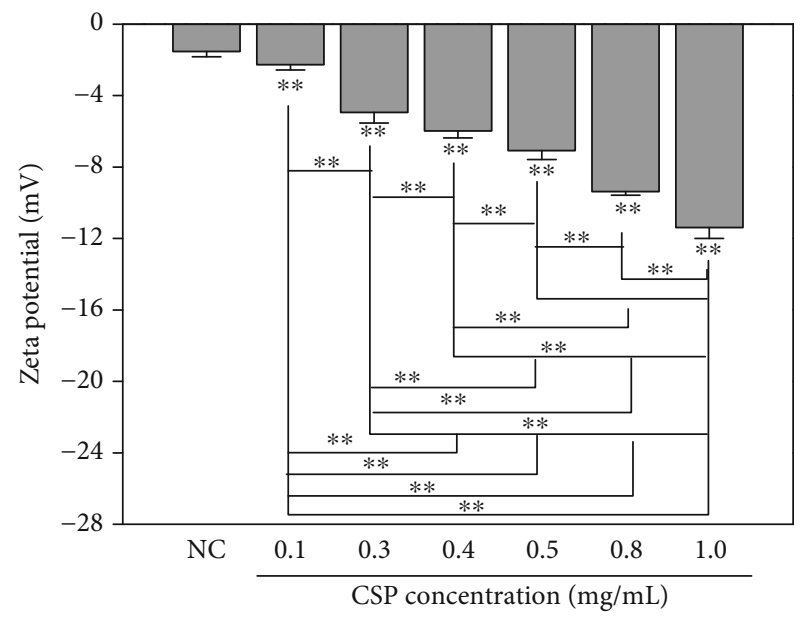

(b)

Figure 6: Zeta potential of CaOx crystals formed under CSP control. (a) Effects of molecular weight. (b) Effects of CSP0 concentration.

In addition to the crystal phase change of $\mathrm{CaOx}$, the crystal morphology also changed. The edges and corners of COM crystals induced by polysaccharide became round and blunt, especially CSP3, and the induced crystal size was relatively small.

\subsection{Effects of Corn Silk Polysaccharides on Zeta Potential of} Crystal. The zeta potential is a measurement of electrostatic repulsive force between particles. When the crystal surface has a high charge density, the absolute value of zeta potential is larger, the crystals do not aggregate easily, and the stability in the solution increases [38].

Figure 6 shows the zeta potentials of the formed $\mathrm{CaOx}$ crystal induced by CSPs.

(1) For polysaccharides with different molecular weights, the zeta potential became more negative from -1.53 to $-11.35 \mathrm{mV}$ as the molecular weight decreased from 124 to $6.0 \mathrm{kDa}$. However, with further decreased molecular weight to $2.0 \mathrm{kDa}$, the zeta potential increased from -11.35 to $-7.8 \mathrm{mV}$. The absolute value of zeta potential of the surface of $\mathrm{CaOx}$ crystal induced by CSP3 with moderate molecular weight was the largest

(2) For one type of polysaccharide (such as CSP0), the zeta potential decreased from -1.53 to $-11.39 \mathrm{mV}$ as CSP0 concentration increased from 0 to $1.0 \mathrm{mg} / \mathrm{mL}$. The more negative the zeta potential was, the more the negatively charged CSP molecules adsorbed on the crystal surface

3.9. TGA Analysis of Calcium Oxalate Crystals Formed in the Presence of CSPi with Different Molecular Weights. As shown in Figure 7, decomposition of $\mathrm{CaOx}$ crystals obtained in the blank group without polysaccharide was divided into three steps. The weight percentages lost were $12.18 \%$ (section $\mathrm{A}, 95.73^{\circ} \mathrm{C}$, corresponding to the loss of structure and surface crystal water), $18.33 \%$ (section $\mathrm{C}, 409.14^{\circ} \mathrm{C}$, corresponding to the decomposition of anhydrous crystals into calcium carbonate), and $28.99 \%$ (section $\mathrm{D}, 552.94^{\circ} \mathrm{C}$, corresponding to decomposition into calcium oxide) (Table 4) $[39,40]$. The theoretical weight loss of pure COM decomposed into $\mathrm{CaC}_{2} \mathrm{O}_{4}, \mathrm{CaCO}_{3}$, and $\mathrm{CaO}$ was $12.33 \%, 19.17 \%$, 


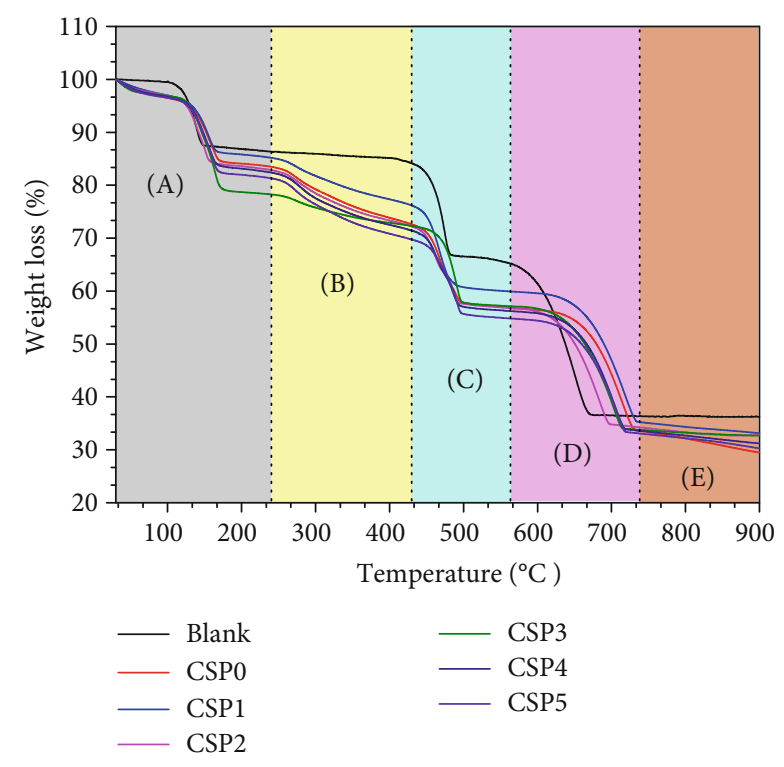

Figure 7: TGA analysis of CaOx crystals formed in the presence of $0.5 \mathrm{mg} / \mathrm{mL}$ CSPi with different molecular weights.

and $30.12 \%$, respectively, which is basically consistent with our results.

The TGA curve of $\mathrm{CaOx}$ crystals formed after adding $0.5 \mathrm{mg} / \mathrm{mL}$ polysaccharide was different from that of the blank group, which was attributed to the COD crystal induced by polysaccharide and CSPi adsorbed by crystal. The coordination bound water of polysaccharide-induced $\mathrm{CaOx}$ crystal was decomposition in the range of $25^{\circ} \mathrm{C}$ to $128^{\circ} \mathrm{C}$ (section A). As the temperature continued to rise to $200^{\circ} \mathrm{C}$ to $400^{\circ} \mathrm{C}$, the polysaccharide molecules adsorbed on the crystal underwent thermal decomposition reaction (section B) [41-43]. As temperature reached $734^{\circ} \mathrm{C}$, the $\mathrm{CaOx}$ sample was decomposed completely (section $\mathrm{E}$ in Figure 7). Finally, the residual weight percentages of $\mathrm{CaOx}$ crystals induced by CSP0, CSP1, CSP2, CSP3, CSP4, and CSP5 were $33.52 \%, 35.15 \%, 34.7 \%, 33.87 \%, 33.68 \%$, and $33.19 \%$, respectively.

No thermogravimetric loss occurred in the blank group at $200^{\circ} \mathrm{C}$ to $400^{\circ} \mathrm{C}$ (section B in Figure 7). However, the crystals induced by CSPs underwent thermal decomposition reaction at this temperature stage. Therefore, the weight loss at this stage can be considered as polysaccharide loss [41-43], that is, the weight of polysaccharide incorporated into the crystal [41]. As can be seen from Figure 7(B), the proportion of CSP3 incorporated into the crystal (4.93\%) was the smallest, but its decomposition temperature was the highest $\left(241.62^{\circ} \mathrm{C}\right)$. In contrast, the proportions of CSP0, CSP1, CSP2, CSP4, and CSP5 polysaccharides incorporated into the crystals were $9.72 \%, 7.67 \%, 9.24 \%, 9.78 \%$, and $10.44 \%$, respectively. However, their decomposition temperatures $\left(221.19^{\circ} \mathrm{C}, 229.44^{\circ} \mathrm{C}, 226.74^{\circ} \mathrm{C}, 225.88^{\circ} \mathrm{C}\right.$, and $\left.223.22^{\circ} \mathrm{C}\right)$ were lower than $241.62^{\circ} \mathrm{C}$ of CSP3. This result indicated that CSP3 had stronger specific interaction with crystals and stronger binding. Given that the incorporation of CSPi made the starting deposition temperature of the "CSPi-crystal" sample higher than that of the pure COM sample, the stability of the "CSPi-crystal" during heating was better than that of the pure crystal in the absence of polysaccharide [41].

3.10. Effects of CSPi on Soluble $\mathrm{Ca}^{2+}$ in Reaction System and Calcium Oxalate Precipitates. The mass of $\mathrm{CaOx}$ precipitate and the concentration of soluble $\mathrm{Ca}^{2+}$ in the supernatant measured by ICP after adding $0.5 \mathrm{mg} / \mathrm{mL}$ CSPi are shown in Figure 8. The molar amount of $\mathrm{CaOx}$ precipitate in the presence of CSPi was lower than that of the blank group (Figure $8(\mathrm{a})$ ), and it was the lowest $(0.0187 \mathrm{mM})$ in the presence of CSP3. After separation of $\mathrm{CaOx}$ precipitates, the concentration of soluble $\mathrm{Ca}^{2+}$ ions $(0.181$ to $0.223 \mathrm{mmoL} / \mathrm{L}$ ) in the supernatant containing polysaccharide was higher than that in the blank group $(0.119 \mathrm{mmoL} / \mathrm{L})$ (Figure $8(\mathrm{~b}))$, and it was the highest $(0.223 \mathrm{mmoL} / \mathrm{L})$ in the presence of CSP3, showing that CSP3 had the strongest ability to complex $\mathrm{Ca}^{2+}$. Figure 8 shows that CSP 3 complexed the most $\mathrm{Ca}^{2+}$, so the concentration of soluble $\mathrm{Ca}^{2+}$ in the supernatant was the largest, whereas the amount of precipitate formed was the smallest, and CSP3 inhibited the formation of $\mathrm{CaOx}$ crystals to the greatest extent.

To verify the reliability of the results in Figure 8 , we calculated the sum of the molar amount of soluble $\mathrm{Ca}^{2+}$ in the supernatant and the molar amount of $\mathrm{Ca}^{2+}$ in the $\mathrm{CaOx}$ precipitates (Table 5). The total molar amount of $\mathrm{Ca}^{2+}$ ions in each group was approximately $0.030 \mathrm{mmol}$, which was the same as the total molar amount of calcium in the reactant $(0.030 \mathrm{mmol})$.

3.11. Effect of Polysaccharides on Crystallization Kinetics of Calcium Oxalate Crystals. Figure 9 shows the effect of six CSPs on the crystallization kinetics of $\mathrm{CaOx}$ crystal. CSP can inhibit the crystallization process of $\mathrm{CaOx}$. In $0.6 \mathrm{mmoL} / \mathrm{L} \mathrm{CaOx}$ solution, the inhibition percentages of $0.5 \mathrm{mg} / \mathrm{mL}$ CSP0, CSP1, CSP2, CSP 3, CSP 4 , and CSP 5 to $\mathrm{CaOx}$ crystallization were $4.1 \%, 12.5 \%, 20.6 \%, 33.1 \%$, $25.5 \%$, and $3.7 \%$, respectively. The order of inhibition ability of CSPs to $\mathrm{CaOx}$ crystal crystallization was CSP3 > CSP4 > CSP2 $>$ CSP1 > CSP0 > CSP5, and the inhibition effect of CSP3 with moderate molecular weight was the best, indicating that the addition of polysaccharides can obviously inhibit the crystallization of CaOx crystal.

3.12. Toxicity Assessment of CSPi on HK-2 Cells. The CCK-8 method was performed to detect the toxicity of CSPi with different molecular weights on normal human kidney proximal tubular epithelial cells (HK-2) (Figure 10(a)). After $24 \mathrm{~h}$ of interaction between HK-2 cells and each CSPi, the cell viability was still above $100 \%$. These results showed that these CSPi caused no cytotoxicity on HK-2 cells and promoted cell growth.

3.13. CSPi Protects HK-2 Cells from Calcium Oxalate Crystal Damage. Figure 10(b) shows the effect of COM crystals with a size of $100 \mathrm{~nm}$ before and after CSPi protection with different molecular weights on the viability of HK-2 cells. After damage of COM crystals for $12 \mathrm{~h}$, cell viability decreased from $100 \%$ to $51.59 \%$, showing that COM had obvious damage to HK-2 cells. 
TABLE 4: TGA analysis of CaOx crystals formed in the presence of CSPs with different molecular weights.

\begin{tabular}{lccccccccc}
\hline CSPs & $\begin{array}{c}\text { A } \\
\text { Decomp. } \\
T^{*}\left({ }^{\circ} \mathrm{C}\right)\end{array}$ & $\begin{array}{c}\text { Weight } \\
\text { lost }(\%)\end{array}$ & $\begin{array}{c}\text { Decomp. } \\
T\left({ }^{\circ} \mathrm{C}\right)\end{array}$ & $\begin{array}{c}\text { Weight } \\
\text { lost }(\%)\end{array}$ & $\begin{array}{c}\text { Decomp. } \\
T\left({ }^{\circ} \mathrm{C}\right)\end{array}$ & $\begin{array}{c}\text { Weight } \\
\text { lost }(\%)\end{array}$ & $\begin{array}{c}\text { Decomp. } \\
T\left({ }^{\circ} \mathrm{C}\right)\end{array}$ & $\begin{array}{c}\text { Weight } \\
\text { lost }(\%)\end{array}$ & $\begin{array}{c}\text { Residual weight } \\
(\%)\end{array}$ \\
\hline Blank & 95.73 & 12.18 & - & - & 409.14 & 18.33 & 552.94 & 28.99 & 36.55 \\
CSP0 & 96.11 & 12.43 & 221.19 & 9.72 & 411.6 & 16.80 & 580.82 & 23.14 & 33.52 \\
CSP1 & 99.45 & 11.02 & 229.44 & 7.67 & 406.35 & 16.72 & 584.59 & 15.59 & 35.15 \\
CSP2 & 90.93 & 13.33 & 226.74 & 9.24 & 410.33 & 15.59 & 568.00 & 21.97 & 34.70 \\
CSP3 & 102.21 & 18.12 & 241.62 & 4.93 & 416.20 & 15.08 & 573.40 & 23.19 & 33.87 \\
CSP4 & 98.78 & 13.50 & 225.88 & 9.78 & 410.88 & 15.41 & 582.69 & 22.33 & 33.68 \\
CSP5 & 100.14 & 14.40 & 223.22 & 10.44 & 417.48 & 14.99 & 583.19 & 21.41 \\
\hline
\end{tabular}

Note: * Decomp. T: decomposition temperature.

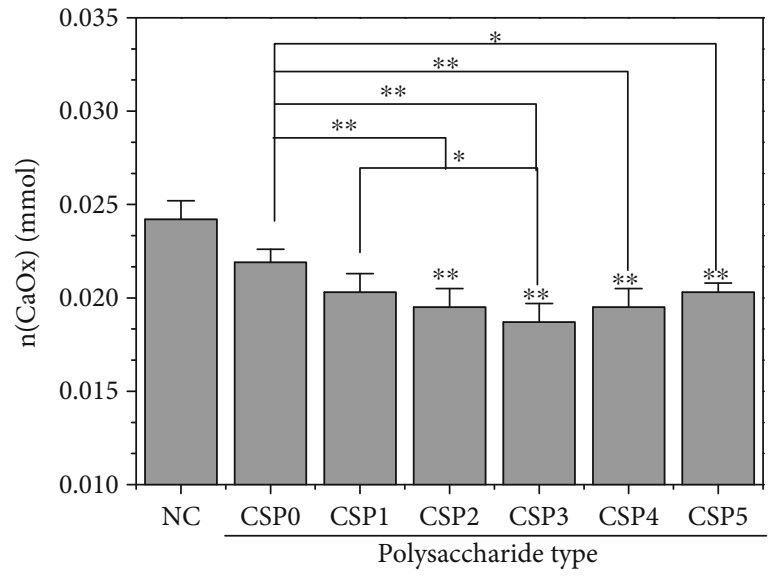

(a)

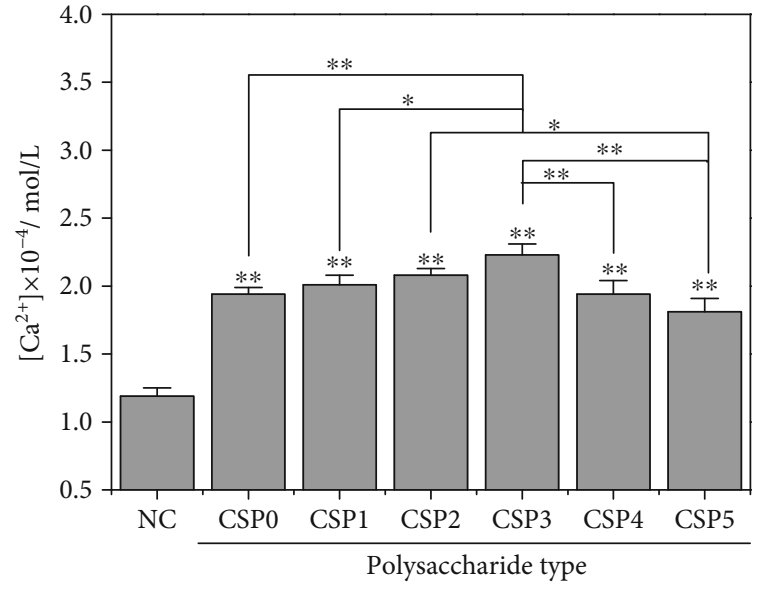

(b)

FIGURE 8: The molar amount of $\mathrm{CaOx}$ precipitation (a) and soluble $\mathrm{Ca}^{2+}$ concentration in the supernatant (b) in the presence of $0.5 \mathrm{mg} / \mathrm{mL}$ CSPs. $\mathrm{c}\left(\mathrm{Ca}^{2+}\right)=\mathrm{c}\left(\mathrm{Ox}^{2-}\right)=0.60 \mathrm{mmol} / \mathrm{L}, \mathrm{c}(\mathrm{NaCl})=10 \mathrm{mmol} / \mathrm{L}$; crystal growth time: $3 \mathrm{~d}$.

TABLE 5: Effect of CSPs with different molecular weights on $\mathrm{CaOx}$ crystal phase, soluble $\mathrm{Ca}^{2+}$ concentration in solution, and CaOx precipitate mass.

\begin{tabular}{|c|c|c|c|c|c|c|c|c|}
\hline CSPs & $\begin{array}{l}\text { Uronic acid } \\
\text { content }(\%)\end{array}$ & COD (\%) & $\begin{array}{c}\mathrm{m}\left(\mathrm{Ca}^{2+}\right) \\
(\mathrm{mg} / \mathrm{L})\end{array}$ & $\begin{array}{c}\mathrm{c}\left(\mathrm{Ca}^{2+}\right) \\
(\mathrm{mmol} / \mathrm{L})\end{array}$ & $\mathrm{n}\left(\mathrm{Ca}^{2+}\right)(\mathrm{mmol})$ & $\begin{array}{l}\text { Mass of } \\
\mathrm{CaOx}(\mathrm{g})\end{array}$ & $\begin{array}{l}\text { Molar amount } \\
\text { of } \mathrm{CaOx}(\mathrm{mmol})\end{array}$ & $\begin{array}{c}\text { Total Ca }{ }^{2+} \\
(\mathrm{mmol})\end{array}$ \\
\hline Blank & - & - & 4.742 & 0.119 & 0.0060 & 0.0031 & 0.0242 & 0.0302 \\
\hline CSP0 & 19.6 & 61.0 & 7.740 & 0.194 & 0.0097 & 0.0027 & 0.0210 & 0.0307 \\
\hline CSP1 & 26.8 & 73.1 & 8.032 & 0.200 & 0.0100 & 0.0026 & 0.0203 & 0.0303 \\
\hline CSP2 & 29.6 & 84.1 & 8.306 & 0.208 & 0.0104 & 0.0025 & 0.0195 & 0.0299 \\
\hline CSP3 & 31.3 & 89.8 & 8.932 & 0.223 & 0.0110 & 0.0024 & 0.0187 & 0.0297 \\
\hline CSP4 & 28.0 & 76.6 & 7.753 & 0.194 & 0.0097 & 0.0025 & 0.0195 & 0.0292 \\
\hline CSP5 & 25.6 & 74.1 & 7.220 & 0.181 & 0.0091 & 0.0026 & 0.0203 & 0.0294 \\
\hline
\end{tabular}

Notes: $\mathrm{m}\left(\mathrm{Ca}^{2+}\right)$ : quality concentration; $\mathrm{c}\left(\mathrm{Ca}^{2+}\right)$ : molar concentration; $\mathrm{n}\left(\mathrm{Ca}^{2+}\right)$ : molar amount.

However, under the protection of CSPi with different molecular weights, the damage of nano-COM to cells was significantly reduced. The cell viabilities of the CSP1, CSP2, CSP3, CSP4, and CSP5 protection groups were $71.56 \%$, $86.07 \%, 93.58 \%, 82.42 \%$, and $77.91 \%$, respectively, and CSP3 had the best protection effect.

3.14. CSPi Protection Reduces Reactive Oxygen Species Levels. Intracellular reactive oxygen species (ROS) increases when
HK-2 cells are damaged. Excessive ROS can quickly react with intracellular macromolecules, causing damage to normal cell function and eventually cell death. This oxidative cell damage can promote the deposition of $\mathrm{CaOx}$ crystals in the kidney [44].

Figure 11 shows the effect of nano-COM crystals on the ROS levels of HK-2 cells before and after CSPi treatment. ROS fluorescence intensity of the normal group was the lowest, that is, ROS was less. ROS fluorescence significantly 


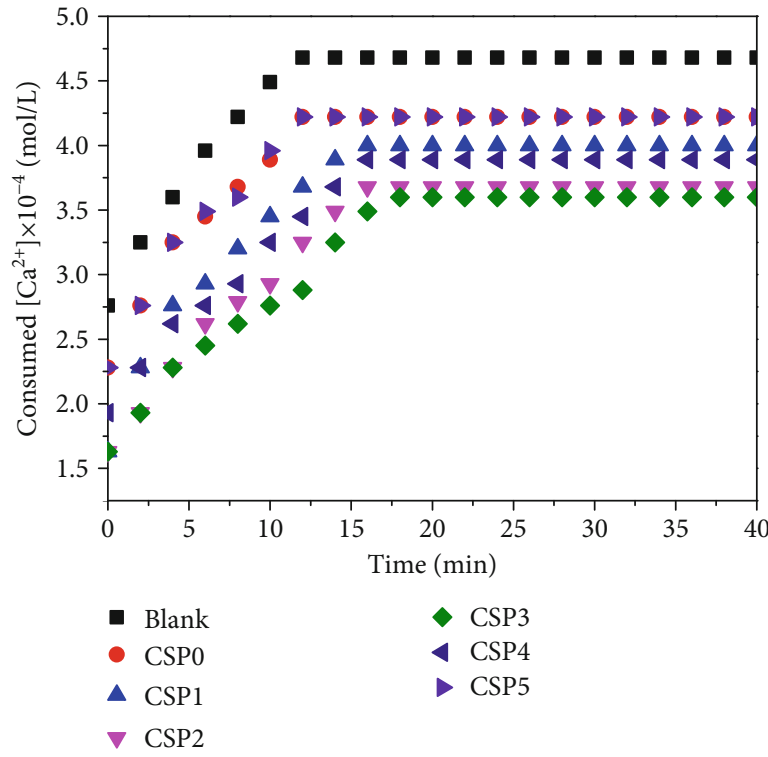

(a)

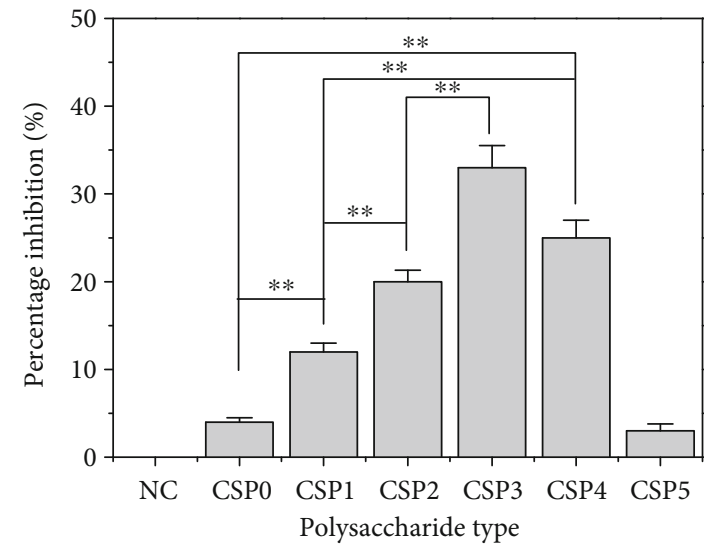

(b)

Figure 9: Consumed $\mathrm{Ca}^{2+}$ concentration in $\mathrm{CaOx}$ solution in the presence of $0.5 \mathrm{mg} / \mathrm{mL}$ CSPs (a). Inhibition percentage of CaOx crystallization by CSPi (b).

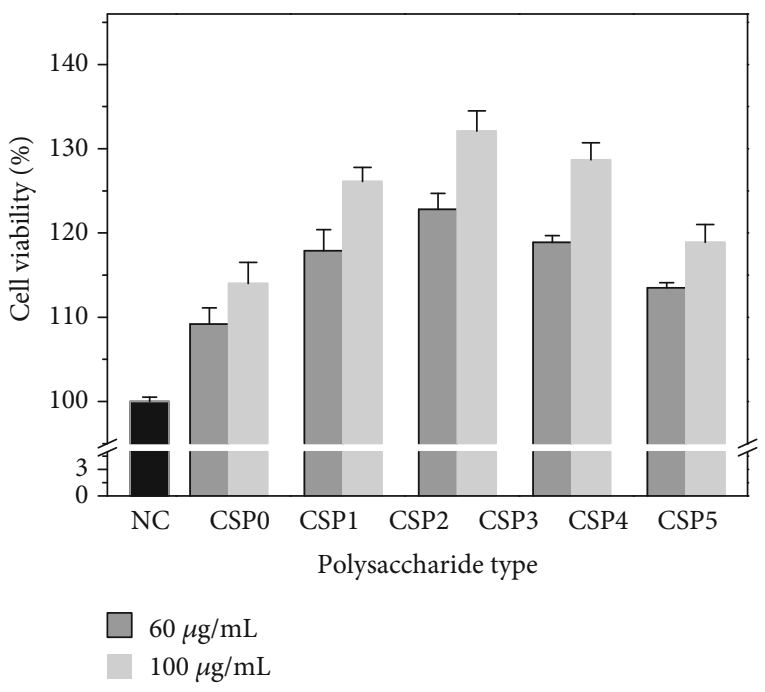

(a)

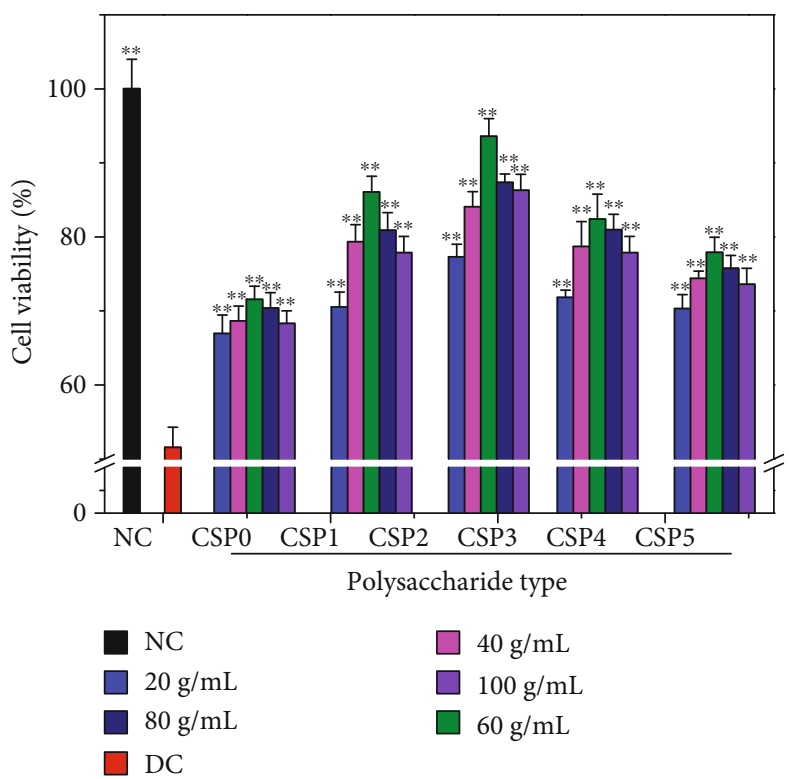

(b)

FIGURE 10: Cytotoxicity of CSPs with different molecular weights (a). Effect of COM crystals on the viability of HK-2 cells before and after CSP protection (b). NC: normal control; DC: damage control. COM concentration: $200 \mu \mathrm{g} / \mathrm{mL}$. Treatment time: $12 \mathrm{~h}$. Compared with the DC group, ${ }^{*} P<0.05 ;{ }^{*} P<0.01$.

increased after damage. ROS fluorescence intensity of the protection group was between those of the normal and injury groups, indicating that CSPi can protect cells from COM crystal damage.

3.15. Protection of Corn Silk Polysaccharides with Different Molecular Weights Reduces Adhesion of Crystals onto Cells. Figure 12 shows the proportion of cells with adhered COM crystals before and after CSP protection by flow cytometry. The proportion of cells in the injury group (54.8\%) was sig- nificantly higher than that in the polysaccharide protection group $(22.8 \%$ to $39.1 \%)$. In other words, CSP3 treatment had the strongest inhibition to the adhesion ability $(22.8 \%)$ of COM crystals to cells.

\section{Discussion}

4.1. Causes of the Greatest Antioxidant Activity of CSP3 with Moderate Molecular Weight 


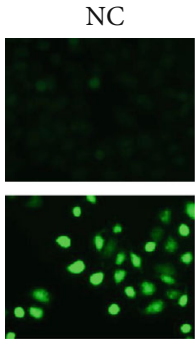

DC
CSP1
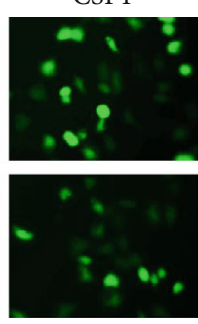

CSP4
CSP2

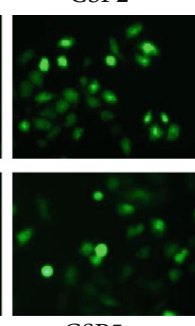

CSP5

(a)

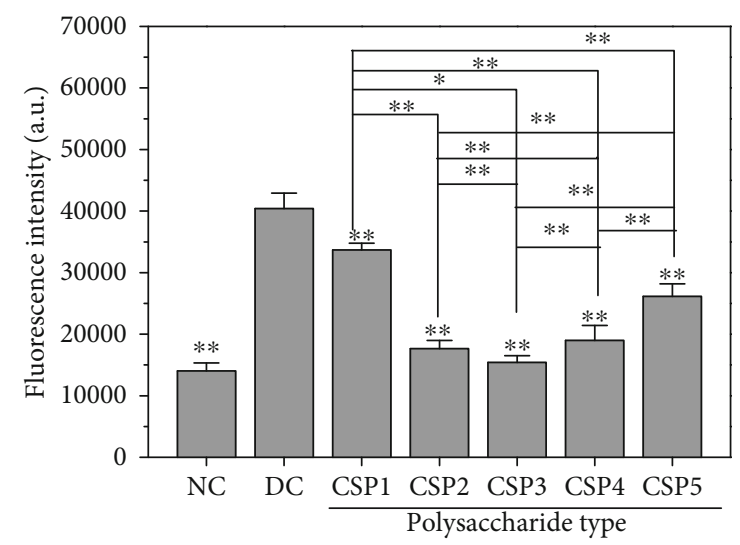

(b)

Figure 11: Effects of nano-COM crystals on ROS levels of HK-2 cells before and after CSP protection with different molecular weights. (a) The images of ROS distribution observed under fluorescence microscope. (b) Quantitative histogram. NC: normal control; DC: damaged control. Polysaccharide concentration: $60 \mu \mathrm{g} / \mathrm{mL}$. COM crystal concentration: $200 \mu \mathrm{g} / \mathrm{mL}$. Treatment time: 12 h. Magnification: 400x. Compared with the DC group, ${ }^{*} P<0.05$; ${ }^{* *} P<0.01$

(1) Effect of Polysaccharide Molecular Weight. As shown in Figure 2, CSP3 with a moderate molecular weight had the strongest antioxidant capacity, whereas CSP0 with the highest molecular weight and CSP5 with the smallest molecular weight had relatively low antioxidant capacity because polysaccharides with too large molecular weights have relatively compact structure, large molecular volume, large steric hindrance, and relatively few exposed active groups [45]. Ultrasonic degradation destroys the hydrogen bond between the intramolecular and intermolecular polymeric chains of the polysaccharide, making the molecular chain of the polysaccharide more expanded [46] and providing sufficient space to bind to the receptor, thereby improving its antioxidant activity.

However, when the molecular weight of polysaccharide is too small, that is, the molecular volume is too small, the polysaccharide cannot easily form a spiral structure with biological activity, the chain structure is destroyed, and the molecular structure is loose [47]; hence, its activity is reduced.
Xu et al. [48] ultrafiltrated and purified four kinds of molecular weight polysaccharides COP1 $(7.9 \mathrm{kDa})$, COP2 $(36 \mathrm{kDa}), \quad \mathrm{COP} 3 \quad(83 \mathrm{kDa})$, and COP4 $(225 \mathrm{kDa})$ from camellia seed polysaccharide. The authors found that $\mathrm{COP} 2$ and $\mathrm{COP} 3$ with moderate molecular weights had stronger free radical scavenging ability and reducing ability than COP1 and COP4. Im et al. [49] isolated three kinds of aloe polysaccharides with molecular weight from aloe and also found that polysaccharides with intermediate molecular weight $(5 \mathrm{kDa}<\mathrm{Mw}<400 \mathrm{kDa})$ had the strongest immunoregulation and antitumor activity on mouse macrophages. Shao et al. [50] found that Sargassum polysaccharide with the highest sulfate content and medium molecular weight had the strongest free radical scavenging ability, reducing ability, and antitumor activity.

(2) Effect of Carboxyl (-COOH) Content in Polysaccharides. The active group $-\mathrm{COOH}$ in polysaccharides can reduce the generation of $\cdot \mathrm{OH}$ and is positively correlated to the content of active groups [47, 51]. Given that CSP3 with a moderate molecular weight had the highest uronic acid content $(31.3 \%$, Table 1$)$, that is, the highest content of $-\mathrm{COOH}, \mathrm{CSP} 3$ had the strongest ability to provide $\mathrm{H}$ for $\cdot \mathrm{OH}$ and the strongest antioxidant activity. The reasons for the highest content of $-\mathrm{COOH}$ in $\mathrm{CSP} 3$ are as follows:

(a) The shear force generated by cavitation at the initial stage of ultrasound destroys noncovalent bonds within and between polysaccharide molecules, polymer clusters will be depolymerized [52], glycosidic linkages are destroyed [20], and $-\mathrm{COOH}$ wrapped in molecules is exposed. Therefore, when the molecular weight is gradually degraded from CSP0 of 124 to $6 \mathrm{kDa}$ (CSP3), the content of $-\mathrm{COOH}$ in the polysaccharides increases

(b) However, with the extension of ultrasonic time, the mechanical force increases, the molecular weight of polysaccharide further decreases, and the volume of polysaccharide molecules further decreases. High-intensity ultrasonic energy may destroy some chemical bonds of the polysaccharides, resulting in decarboxylation reaction [53, 54]. Moreover, linear CSP molecules with galacturonic acid undergo different degrees of esterification, and the degree of esterification is high when the molecular volume is small [55]. Therefore, the content of $-\mathrm{COOH}$ in polysaccharides with low molecular weight (such as CSP4 and CSP5) decreases again

4.2. Reasons for CSPs to Inhibit Calcium Oxalate MonohydrateInduced Calcium Oxalate Dihydrate Formation. The schematic diagram of the regulation of $\mathrm{CaOx}$ crystals by CSPs with different molecular weights is shown in Figure 13. In the absence of polysaccharides, the generated $\mathrm{CaOx}$ crystals 

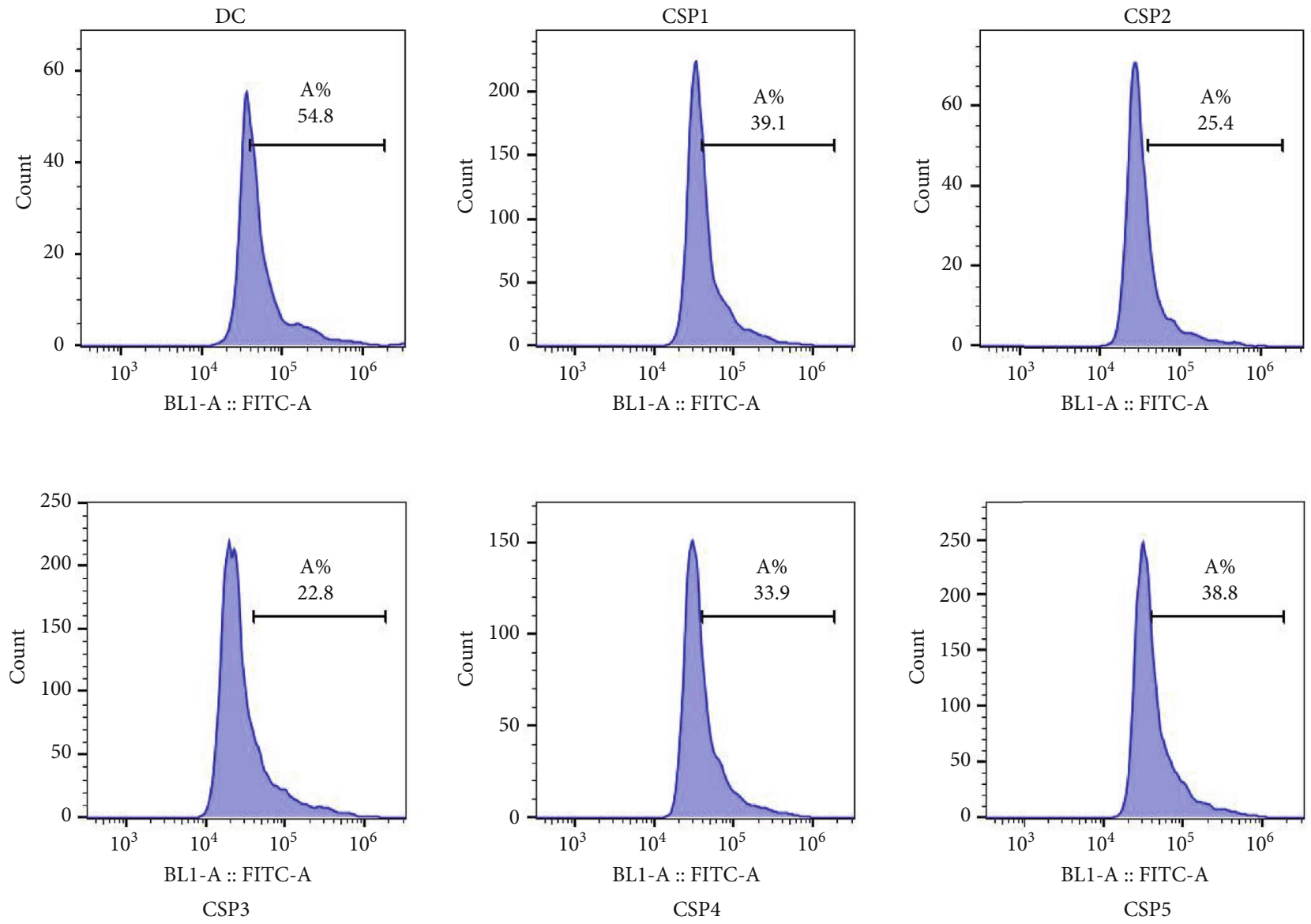

(a)

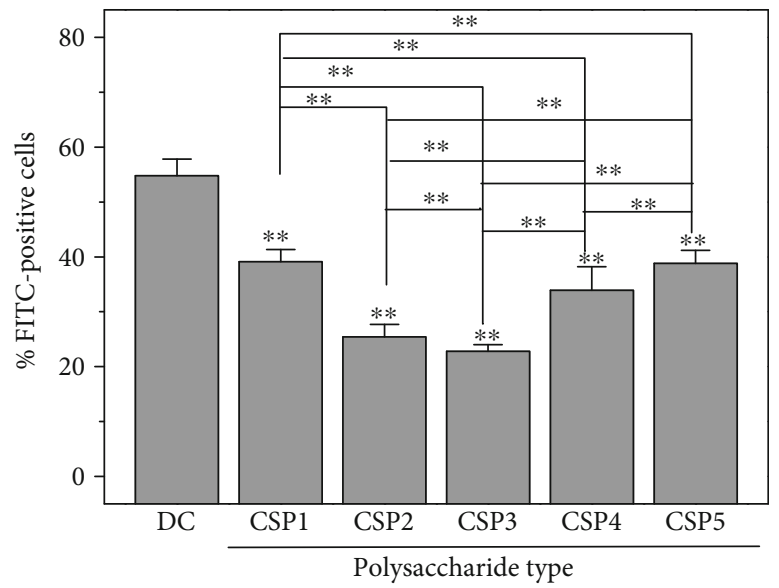

(b)

FIGURE 12: The proportion of cells with adhered COM crystals before and after CSP protection with different molecular weights. (a) Flow histogram. (b) Statistical results. DC: damaged control. Polysaccharide concentration: $60 \mu \mathrm{g} / \mathrm{mL}$. COM crystal concentration: $200 \mu \mathrm{g} / \mathrm{mL}$. Treatment time: $12 \mathrm{~h}$. Compared with the DC group, ${ }^{*} P<0.05$; ${ }^{* *} P<0.01$.

were all COM (Figures 3(a) and 5(a)). After adding CSPs, COD crystals were induced, and approximately $4.93 \%$ of CSP3, 7.67\% of CSP1, 9.24\% of CSP2, $9.72 \%$ of CSP0, $9.78 \%$ of CSP 4 , and $10.44 \%$ of CSP5 were incorporated into the crystals (Figure 7), forming a "CSPi-crystal" complex in which "CSP3-crystal" had the highest thermal decomposition temperature, that is, the best thermal sta- bility. Given that the $-\mathrm{COOH}$ group in CSP can interact with the surface of $\mathrm{COM}$ crystal through calcium bridge ( $_{\text {(CSP) }} \mathrm{COO}-\ldots \mathrm{Ca}^{2+} \ldots-\mathrm{OOC}\left({ }_{(\mathrm{COM})}\right)$, which prevents free $\mathrm{Ca}^{2+}$ from penetrating into the lattice of COM, thus inhibiting the formation of COM crystal [28].

The -COOH groups in CSP can complex free $\mathrm{Ca}^{2+}$ in solution, increase $\mathrm{Ca}^{2+}$ enrichment on polysaccharide 


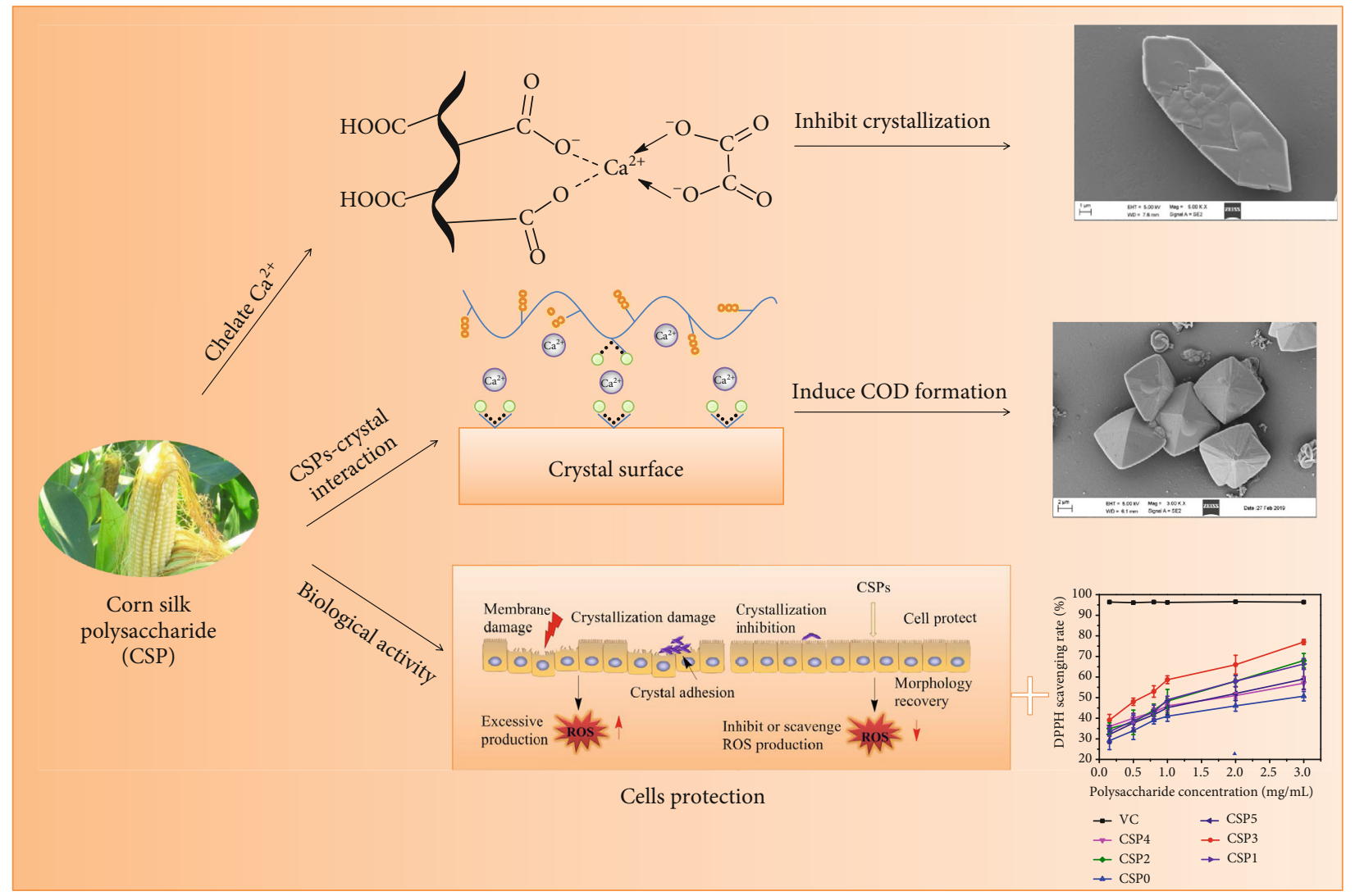

Figure 13: Schematic diagram of the regulation of $\mathrm{CaOx}$ crystals and protection effect on oxidative damage in renal epithelial cells in the presence of CSPs.

surface, and form high-energy interface on the polysaccharide surface. Moreover, the adsorption of $\mathrm{Ca}^{2+}$ by $-\mathrm{COOH}$ in CSP reduces the degree of freedom of $\mathrm{Ca}^{2+}$, increases the $\left[\mathrm{Ca}^{2+}\right] /\left[\mathrm{Ox}^{2-}\right]$ ratio in local areas, and increases the energy state of calcium. Both high-energy interface and highcalcium energy state can promote thermodynamic metastable COD formation [56].

Given that CSP3 had a high content of $-\mathrm{COOH}$, a small molecular volume, and the strongest complexing ability to free $\mathrm{Ca}^{2+}$ in solution, CSP3 had the best inhibitory effect on $\mathrm{CaOx}$ crystals and the highest percentage of induced COD (Figure 3(c)). COD is less toxic to renal epithelial cells than COM $[57,58]$, and COD is easier to excrete through urine [59]; therefore, inhibiting the formation of COM is more beneficial for inhibiting the formation of kidney stones.

4.3. Corn Silk Polysaccharides Induce Calcium Oxalate Monohydrate Crystals with Rounded Corners and Small Size. The corners and edges of COM crystals induced by polysaccharide became round and blunt, especially CSP3, and the induced crystal size was relatively small (Figure 5) because $\mathrm{Ca}^{2+}$ at the tip and edge of COM crystals easily coordinated with $-\mathrm{COOH}$ in the polysaccharides, resulting in dissociation-precipitation equilibrium of COM crystals. Continuous dissociation-precipitation eventually made the COM crystals round and blunt.

Calcium oxalate crystals with sharp edges and corners are more likely to cause cell membrane rupture, thereby exacer- bating cell damage [60]. CSPs induced the formation of round blunt crystals, which reduced the possible mechanical damage of the crystals to the cells and reduced the generation of cell membrane debris, thus inhibiting the nucleation of microcrystals. In addition, small round blunt crystals are easier to be excreted out of the body with urine, this reducing the risk of crystal retention. Therefore, inducing the formation of small round blunt crystals is conducive to inhibiting the formation of stones.

4.4. CSPs Protect HK-2 Cells from Calcium Oxalate Crystal Damage. The schematic diagram of the protection effect on oxidative damage in renal epithelial cells in the presence of CSPs is shown in Figure 13. CSPs with different molecular weights not only did not express toxicity to HK-2 cells but also promoted growth (Figure 9(a)). The protection of CSPs with different molecular weights on HK-2 cells inhibited the damage of COM crystal to cells, enhanced cell viability (Figure 9(b)), and reduced the level of ROS (Figure 10). Oxidative stress induced by ROS and free radical damages cell structure and function of biomolecules, leading to the formation of many diseases [47]. CSPs can effectively scavenge free radicals (Figure 2), reduce the level of ROS, protect cells from damage, and inhibit the adhesion of crystals onto cells (Figure 11). CSPs' inhibition of COM crystal adhesion is also related to its ability to increase the negative charge on the surface of COM crystal after adsorption on the crystal surface, thereby increasing the absolute value of zeta potential 
(Figure 6). High absolute value of zeta potential can increase the repulsive force between crystal and cell and reduce the adhesion between them $[8,61]$. The protection ability of each CSPi is consistent with its antioxidant ability, that is, CSP3 had the greatest cell protective ability.

$\mathrm{Li}$ et al. [62] reported that Lycium barbarum polysaccharide (LBP-4a) has protective effects on $\mathrm{KBrO}_{3}$-induced renal injury in rats. Protection of LBP-4a can increase the activity of antioxidant enzymes in rat kidney tissue, decrease mitochondrial membrane potential, and reduce DNA damage in renal cells. Li et al. [63] reported that laminarin has a protective effect on glycerol-induced kidney injury in mice, and laminarin with moderate molecular weight has the best protective effect on the kidney. Acidic polysaccharides can enhance antioxidant enzyme level and reduce oxygen free radicals.

\section{Conclusions}

CSP0 with a molecular weight of $124 \mathrm{kDa}$ was degraded by ultrasonication, and five degraded polysaccharides with molecular weights of $26.1,12.2,6.0,3.5$, and $2.0 \mathrm{kDa}$ were obtained. The structure was characterized by FT-IR and NMR analyses. These CSPs exhibited scavenging activity on hydroxyl and DPPH, as well as reducing power and chelation ability for ferrous ions. Each CSPi can increase the concentration of soluble $\mathrm{Ca}^{2+}$ in the solution, reduce the quality of $\mathrm{CaOx}$ crystals, inhibit COD to COM conversion, increase the absolute value of zeta potential of the crystal surface, and reduce the degree of crystal aggregation and COM crystal size. These CSPs induced no cytotoxicity on HK-2 cells, protected HK-2 cells from damage by nano-COM crystals and increased cell vitality, and reduced the level of ROS and the adhesion of crystals onto cells. The activity of CSPs was closely correlated with the molecular weight, i.e., very high or very low molecular weight of CSPs was not conducive to CSP activity. CSP3 with a moderate molecular weight had the best antioxidant effect and the best cell protection effect. Overall, our results suggested that each CSPi, especially CSP3, may be potential antistone drugs.

\section{Data Availability}

The data used to support the findings of this study are available from the corresponding author upon request.

\section{Conflicts of Interest}

There are no conflicts of interest to declare.

\section{Authors' Contributions}

Jia-Yun Chen and Xin-Yuan Sun have contributed equally to this work.

\section{Acknowledgments}

This work was granted by the National Natural Science Foundation of China (Nos. 21975105 and 21701050) and the Guangdong Provincial Science and Technology Plan Project (No. 2017B030314108).

\section{References}

[1] A. Mittal, S. Tandon, S. K. Singla, and C. Tandon, "In vitro inhibition of calcium oxalate crystallization and crystal adherence to renal tubular epithelial cells by Terminalia arjuna," Urolithiasis, vol. 44, no. 2, pp. 117-125, 2016.

[2] M. Daudon, A. Dessombz, V. Frochot et al., "Comprehensive morpho-constitutional analysis of urinary stones improves etiological diagnosis and therapeutic strategy of nephrolithiasis," Comptes Rendus Chimie, vol. 19, no. 11-12, pp. 1470-1491, 2016.

[3] Y.-W. Zhao, D. Guo, C.-Y. Li, and J.-M. Ouyang, "Comparison of the adhesion of calcium oxalate monohydrate to HK-2 cells before and after repair using tea polysaccharides," International Journal of Nanomedicine, vol. Volume 14, pp. 42774292, 2019.

[4] M. A. El-Salam, J. K. Bastos, J. J. Han et al., “The synthesized plant metabolite 3,4,5-Tri-O-galloylquinic acid methyl ester inhibits calcium oxalate crystal growth in a Drosophila model, downregulates renal cell surface annexin a1 expression, and decreases crystal adhesion to cells," Journal of Medicinal Chemistry, vol. 61, no. 4, pp. 1609-1621, 2018.

[5] J. Han, D. Guo, X.-Y. Sun, J.-M. Wang, J.-M. Ouyang, and B.-S. Gui, "Repair effects of astragalus polysaccharides with different molecular weights on oxidatively damaged HK-2 cells," Scientific Reports, vol. 9, no. 1, p. 9871, 2019.

[6] H. Zhang, X. Y. Sun, and J. M. Ouyang, "Effects of Porphyra yezoensis polysaccharide with different molecular weights on the adhesion and endocytosis of nanocalcium oxalate monohydrate in repairing damaged HK-2 cells," ACS Biomaterials Science \& Engineering, vol. 5, no. 8, pp. 3974-3986, 2019.

[7] Z.-H. Zhang, S.-T. Fan, D.-F. Huang et al., "Effect of Lactobacillus plantarum NCU116 fermentation on Asparagus officinalis polysaccharide: characterization, antioxidative, and immunoregulatory activities," Journal of Agricultural and Food Chemistry, vol. 66, no. 41, pp. 10703-10711, 2018.

[8] D. L. Gomes, K. R. T. Melo, M. F. Queiroz et al., "In vitro studies reveal antiurolithic effect of antioxidant sulfated polysaccharides from the green seaweed Caulerpa cupressoides var flabellata," Marine drugs, vol. 17, no. 6, p. 326, 2019.

[9] L. S. Huang, X. Y. Sun, Q. Gui, and J. M. Ouyang, "Effects of plant polysaccharides with different carboxyl group contents on calcium oxalate crystal growth," CrystEngComm, vol. 19, no. 32, pp. 4838-4847, 2017.

[10] Y. Qin, L. Xiong, M. Li et al., "Preparation of bioactive polysaccharide nanoparticles with enhanced radical scavenging activity and antimicrobial activity," Journal of Agricultural and Food Chemistry, vol. 66, no. 17, pp. 4373-4383, 2018.

[11] Y. Liu, Y. Sun, and G. Huang, "Preparation and antioxidant activities of important traditional plant polysaccharides," International Journal of Biological Macromolecules, vol. 111, pp. 780-786, 2018.

[12] Y. Pan, C. Wang, Z. Chen, W. Li, G. Yuan, and H. Chen, "Physicochemical properties and antidiabetic effects of a polysaccharide from corn silk in high-fat diet and streptozotocininduced diabetic mice," Carbohydrate Polymers, vol. 164, pp. 370-378, 2017.

[13] T. Y. Ho, C. C. Li, H. Y. Lo, F. Y. Chen, and C. Y. Hsiang, "Corn silk extract and its bioactive peptide ameliorated 
lipopolysaccharide-induced inflammation in mice via the nuclear factor- $\kappa \mathrm{b}$ signaling pathway," Journal of Agricultural and Food Chemistry, vol. 65, no. 4, pp. 759-768, 2017.

[14] Y. T. He, H. N. Gao, Y. X. Xu, X. M. Pan, and J. R. Li, “Chemical analysis and antioxidant activities in vitro of polysaccharide extracted from corn silk," Advanced Engineering Materials, vol. 535-537, pp. 2335-2339, 2012.

[15] Q. Guo, L. Xu, Y. Chen et al., "Structural characterization of corn silk polysaccharides and its effect in $\mathrm{H}_{2} \mathrm{O}_{2}$ induced oxidative damage in L6 skeletal muscle cells," Carbohydrate Polymers, vol. 208, pp. 161-167, 2019.

[16] H. Zhao, Y. Zhang, Z. Liu et al., "Acute toxicity and antifatigue activity of polysaccharide-rich extract from corn silk," Biomedicine \& Pharmacotherapy, vol. 90, pp. 686-693, 2017.

[17] S. Chen, H. Chen, J. Tian, Y. Wang, L. Xing, and J. Wang, "Chemical modification, antioxidant and $\alpha$-amylase inhibitory activities of corn silk polysaccharides," Carbohydrate Polymers, vol. 98, no. 1, pp. 428-437, 2013.

[18] D. Guo, K. Yu, X.-Y. Sun, and J.-M. Ouyang, "Structural characterization and repair mechanism of Gracilaria lemaneiformis sulfated polysaccharides of different molecular weights on damaged renal epithelial cells," Oxidative Medicine and Cellular Longevity, vol. 2018, Article ID 7410389, 15 pages, 2018.

[19] J.-L. Hu, S.-P. Nie, C. Li, S. Wang, and M.-Y. Xie, "Ultrasonic irradiation induces degradation and improves prebiotic properties of polysaccharide from seeds of Plantago asiatica L. during in vitro fermentation by human fecal microbiota," Food Hydrocolloids, vol. 76, pp. 60-66, 2018.

[20] J.-K. Yan, J.-J. Pei, H.-L. Ma, and Z.-B. Wang, "Effects of ultrasound on molecular properties, structure, chain conformation and degradation kinetics of carboxylic curdlan," Carbohydrate Polymers, vol. 121, pp. 64-70, 2015.

[21] X.-Y. Sun, J.-M. Ouyang, A.-J. Liu, Y.-M. Ding, and Q.-Z. Gan, "Preparation, characterization, and in vitro cytotoxicity of COM and COD crystals with various sizes," Materials Science and Engineering: C, vol. 57, pp. 147-156, 2015.

[22] P. Bhadja, C.-Y. Tan, J.-M. Ouyang, and K. Yu, "Repair effect of seaweed polysaccharides with different contents of sulfate group and molecular weights on damaged HK-2 cells," Polymers, vol. 8, no. 5, p. 188, 2016.

[23] L. Gong, H. Zhang, Y. Niu et al., “A novel alkali extractable polysaccharide from Plantago asiatic L. seeds and its radicalscavenging and bile acid-binding activities," Journal of Agricultural and Food Chemistry, vol. 63, no. 2, pp. 569-577, 2015.

[24] L. Yang, T. Zhao, H. Wei et al., "Carboxymethylation of polysaccharides from Auricularia auricula and their antioxidant activities in vitro," International Journal of Biological Macromolecules, vol. 49, no. 5, pp. 1124-1130, 2011.

[25] X. Li, Y. Lu, W. Zhang et al., "Antioxidant capacity and cytotoxicity of sulfated polysaccharide TLH-3 from Tricholoma lobayense," International Journal of Biological Macromolecules, vol. 82, pp. 913-919, 2016.

[26] L. Sun, C. Wang, Q. Shi, and C. Ma, "Preparation of different molecular weight polysaccharides from Porphyridium cruentum and their antioxidant activities," International Journal of Biological Macromolecules, vol. 45, no. 1, pp. 42-47, 2009.

[27] J. Gao, T. Zhang, Z. Y. Jin et al., "Structural characterisation, physicochemical properties and antioxidant activity of polysaccharide from Lilium lancifolium Thunb.," Food Chemistry, vol. 169, pp. 430-438, 2015.
[28] J. Chung, I. Granja, M. G. Taylor, G. Mpourmpakis, J. R. Asplin, and J. D. Rimer, "Molecular modifiers reveal a mechanism of pathological crystal growth inhibition," Nature, vol. 536, no. 7617, pp. 446-450, 2016.

[29] S. Farmanesh, S. Ramamoorthy, J. Chung, J. R. Asplin, P. Karande, and J. D. Rimer, "Specificity of growth inhibitors and their cooperative effects in calcium oxalate monohydrate crystallization," Journal of the American Chemical Society, vol. 136, no. 1, pp. 367-376, 2013.

[30] C. Zhong, Z. Deng, R. Wang, and Y. Bai, "Inhibition mechanism of calcium oxalate crystal growth by cooperation influence of colloidal selenium nanoparticles and bovine serum albumin," Crystal Growth \& Design, vol. 15, no. 4, pp. 16021610, 2015.

[31] Q. Guo, Z. Chen, R. K. Santhanam et al., "Hypoglycemic effects of polysaccharides from corn silk (Maydis stigma) and their beneficial roles via regulating the PI3K/Akt signaling pathway in L6 skeletal muscle myotubes," International Journal of Biological Macromolecules, vol. 121, pp. 981-988, 2019.

[32] S. Jayaram, S. Kapoor, and S. M. Dharmesh, "Pectic polysaccharide from corn (Zea mays L) effectively inhibited multistep mediated cancer cell growth and metastasis," ChemicoBiological Interactions, vol. 235, pp. 63-75, 2015.

[33] S. Chen, H. Chen, J. Tian, J. Wang, Y. Wang, and L. Xing, "Enzymolysis-ultrasonic assisted extraction, chemical characteristics and bioactivities of polysaccharides from corn silk," Carbohydrate Polymers, vol. 101, pp. 332-341, 2014.

[34] M. K. Patel, B. Tanna, A. Mishra, and B. Jha, "Physicochemical characterization, antioxidant and anti-proliferative activities of a polysaccharide extracted from psyllium ( $P$. ovata) leaves," International Journal of Biological Macromolecules, vol. 118, no. Part A, pp. 976-987, 2018.

[35] X. L. Li, X. F. Tu, K. Thakur et al., "Effects of different chemical modifications on the antioxidant activities of polysaccharides sequentially extracted from peony seed dreg," International Journal of Biological Macromolecules, vol. 112, pp. 675-685, 2018.

[36] X.-Y. Sun, C.-Y. Zhang, P. Bhadja, and J.-M. Ouyang, "Preparation, properties, formation mechanisms, and cytotoxicity of calcium oxalate monohydrate with various morphologies," CrystEngComm, vol. 20, no. 1, pp. 75-87, 2018.

[37] X.-Y. Sun, J.-M. Ouyang, and K. Yu, "Shape-dependent cellular toxicity on renal epithelial cells and stone risk of calcium oxalate dihydrate crystals," Scientific Reports, vol. 7, no. 1, p. 7250, 2017.

[38] A. Stanković, J. Kontrec, B. N. Džakula, D. Kovačević, B. Marković, and D. Kralj, "Preparation and characterization of calcium oxalate dihydrate seeds suitable for crystal growth kinetic analyses," Journal of Crystal Growth, vol. 500, pp. 9197, 2018.

[39] V. S. Joshi, B. B. Parekh, M. J. Joshi, and A. B. Vaidya, "Herbal extracts of Tribulus terrestris and Bergenia ligulata inhibit growth of calcium oxalate monohydrate crystals in vitro," Journal of Crystal Growth, vol. 275, no. 1-2, pp. e1403-e1408, 2005.

[40] J. Ihli, Y.-W. Wang, B. Cantaert et al., "Precipitation of amorphous calcium oxalate in aqueous solution," Chemistry of Materials, vol. 27, no. 11, pp. 3999-4007, 2015.

[41] W. Fang, H. Zhang, J. Yin et al., "Hydroxyapatite crystal formation in the presence of polysaccharide," Crystal Growth of Design, vol. 16, no. 3, pp. 1247-1255, 2016. 
[42] W. Zhang, J. Huang, W. Wang et al., "Extraction, purification, characterization and antioxidant activities of polysaccharides from Cistanche tubulosa," International Journal of Biological Macromolecules, vol. 93, no. Part A, pp. 448-458, 2016.

[43] Q. Guo, Q. Ma, Z. Xue, X. Gao, and H. Chen, "Studies on the binding characteristics of three polysaccharides with different molecular weight and flavonoids from corn silk (Maydis stigma)," Carbohydrate Polymers, vol. 198, pp. 581-588, 2018.

[44] Y. Li, J. Zhang, H. Liu et al., "Curcumin ameliorates glyoxylateinduced calcium oxalate deposition and renal injuries in mice," Phytomedicine, vol. 61, p. 152861, 2019.

[45] M. Jiangwei, Q. Zengyong, and X. Xia, "Optimisation of extraction procedure for black fungus polysaccharides and effect of the polysaccharides on blood lipid and myocardium antioxidant enzymes activities," Carbohydrate Polymers, vol. 84, no. 3, pp. 1061-1068, 2011.

[46] X. Sun, C. Zhao, W. Pan, J. Wang, and W. Wang, "Carboxylate groups play a major role in antitumor activity of Ganoderma applanatum polysaccharide," Carbohydrate Polymers, vol. 123, pp. 283-287, 2015.

[47] J. Wang, S. Hu, S. Nie, Q. Yu, and M. Xie, "Reviews on mechanisms of in vitro antioxidant activity of polysaccharides," Oxidative Medicine and Cellular Longevity, vol. 2016, no. 64, Article ID 5692852, 13 pages, 2016.

[48] Z. Xu, X. Li, S. Feng et al., "Characteristics and bioactivities of different molecular weight polysaccharides from camellia seed cake," International Journal of Biological Macromolecules, vol. 91, pp. 1025-1032, 2016.

[49] S. A. Im, S. T. Oh, S. Song et al., "Identification of optimal molecular size of modified Aloe polysaccharides with maximum immunomodulatory activity," International Immunopharmacology, vol. 5, no. 2, pp. 271-279, 2005.

[50] P. Shao, X. Chen, and P. Sun, "Chemical characterization, antioxidant and antitumor activity of sulfated polysaccharide from Sargassum horneri," Carbohydrate Polymers, vol. 105, pp. 260269, 2014.

[51] X. T. Li, Y. K. Zhang, H. X. Kuang et al., "Mitochondrial protection and anti-aging activity of astragalus polysaccharides and their potential mechanism," International Journal of Molecular Sciences, vol. 13, no. 2, pp. 1747-1761, 2012.

[52] T. Wu, S. Zivanovic, D. G. Hayes, and J. Weiss, "Efficient reduction of chitosan molecular weight by high-intensity ultrasound: underlying mechanism and effect of process parameters," Journal of Agricultural and Food Chemistry, vol. 56, no. 13, pp. 5112-5119, 2008.

[53] K. Zhong, Q. Zhang, L. Tong, L. Liu, X. Zhou, and S. Zhou, "Molecular weight degradation and rheological properties of schizophyllan under ultrasonic treatment," Ultrasonics Sonochemistry, vol. 23, pp. 75-80, 2015.

[54] S. Li, Q. Xiong, X. Lai et al., "Molecular modification of polysaccharides and resulting bioactivities," Comprehensive Reviews in Food Science and Food Safety, vol. 15, no. 2, pp. 237-250, 2016.

[55] M. Y. Sayah, R. Chabir, H. Benyahia et al., "Yield, esterification degree and molecular weight evaluation of pectins isolated from orange and grapefruit peels under different conditions," PLoS One, vol. 11, no. 9, article e0161751, 2016.

[56] B. Grohe, K. A. Rogers, H. A. Goldberg, and G. K. Hunter, "Crystallization kinetics of calcium oxalate hydrates studied by scanning confocal interference microscopy," Journal of Crystal Growth, vol. 295, no. 2, pp. 148-157, 2006.
[57] J. W. M. Yuen, M.-D. I. Gohel, N.-w. Poon, D. K. Y. Shum, P.-c. Tam, and D. W. T. Au, "The initial and subsequent inflammatory events during calcium oxalate lithiasis," Clinica Chimica Acta, vol. 411, no. 15-16, pp. 1018-1026, 2010.

[58] X. Y. Sun, J. M. Ouyang, W. Y. Zhu, Y. B. Li, and Q. Z. Gan, "Size-dependent toxicity and interactions of calcium oxalate dihydrate crystals on vero renal epithelial cells," Journal of Materials Chemistry B, vol. 3, no. 9, pp. 1864-1878, 2015.

[59] X. Y. Sun, J. M. Ouyang, Y. B. Li, and X. L. Wen, "Mechanism of cytotoxicity of micron/nano calcium oxalate monohydrate and dihydrate crystals on renal epithelial cells," RSC Advances, vol. 5, no. 56, pp. 45393-45406, 2015.

[60] X. Y. Sun, M. Xu, and J. M. Ouyang, "Effect of crystal shape and aggregation of calcium oxalate monohydrate on cellular toxicity in renal epithelial cells," ACS Omega, vol. 2, no. 9, pp. 6039-6052, 2017.

[61] X. Y. Sun, J. M. Ouyang, and M. Xu, "Synthesis, characterization, and cytotoxicity assay of calcium oxalate dihydrate crystals in various shapes," CrystEngComm, vol. 18, no. 29, pp. 5463-5473, 2016.

[62] J. Li, M. Shi, B. Ma, Y. Zheng, R. Niu, and K. Li, "Protective effects of fraction $4 \mathrm{a}$ of polysaccharides isolated from lycium barbarum against $\mathrm{KBrO}_{3}$-induced renal damage in rats," Food \& Function, vol. 8, no. 7, pp. 2566-2572, 2017.

[63] X. Li, J. Wang, H. Zhang, and Q. Zhang, "Renoprotective effect of low-molecular-weight sulfated polysaccharide from the seaweed Laminaria japonica on glycerol-induced acute kidney injury in rats," International Journal of Biological Macromolecules, vol. 95, pp. 132-137, 2017. 


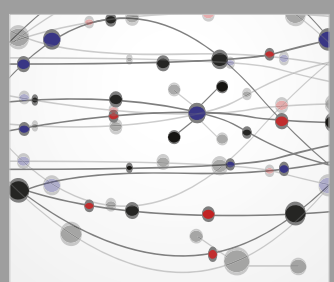

The Scientific World Journal
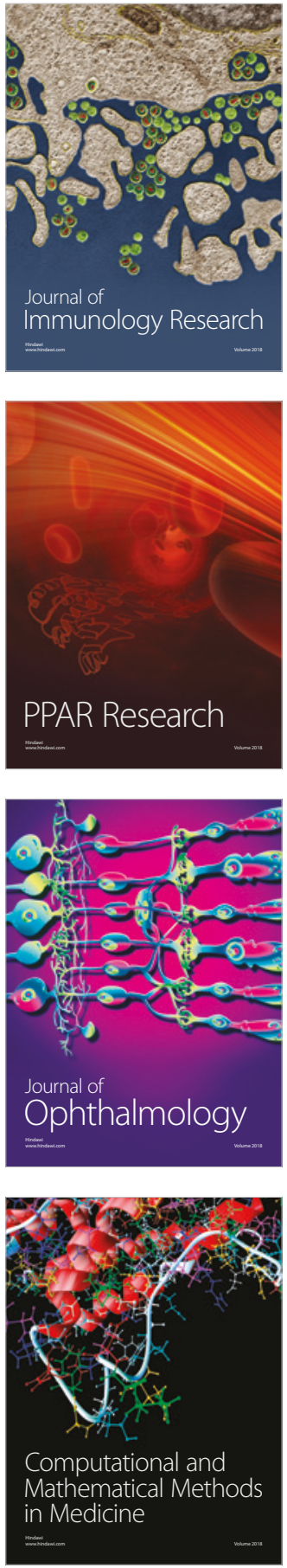

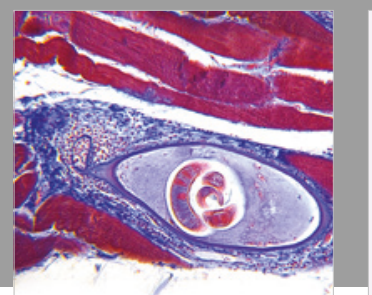

Gastroenterology Research and Practice

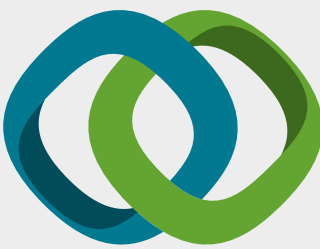

\section{Hindawi}

Submit your manuscripts at

www.hindawi.com
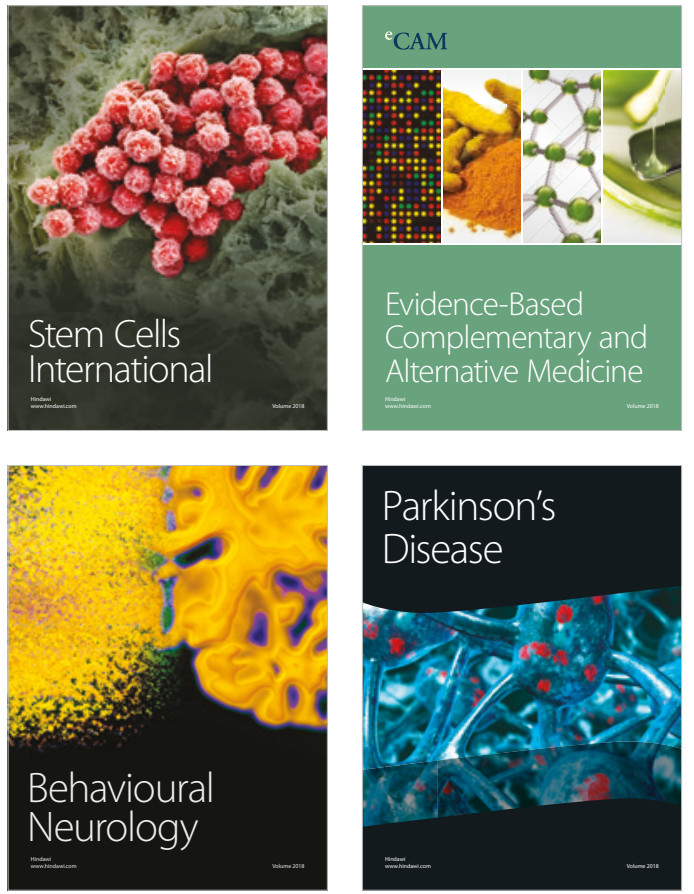

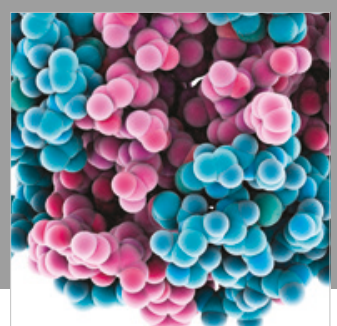

ournal of

Diabetes Research

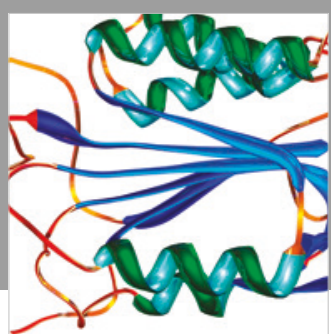

Disease Markers
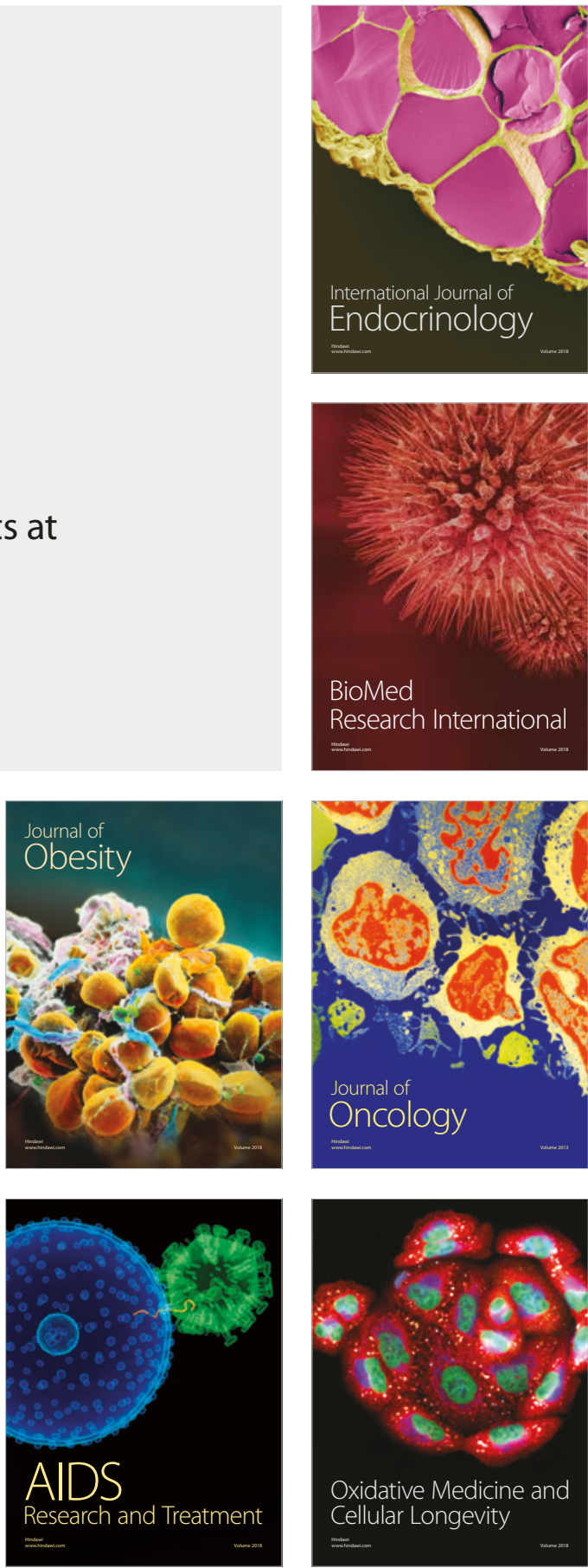